\title{
R-Allyl Nickel(II) Complexes with Chelating N-Heterocyclic Carbenes: Synthesis, Structural Characterization, and Catalytic Activity
}

\author{
Lourdes Benítez Junquera, M. Carmen Puerta,* and Pedro Valerga* \\ Departamento de Ciencia de los Materiales e Ingeniería Metalúrgica y Química Inorgánica, Facultad de Ciencias, Universidad de \\ Cádiz, 11510 Puerto Real, Cádiz, España
}

\section{Supporting Information}
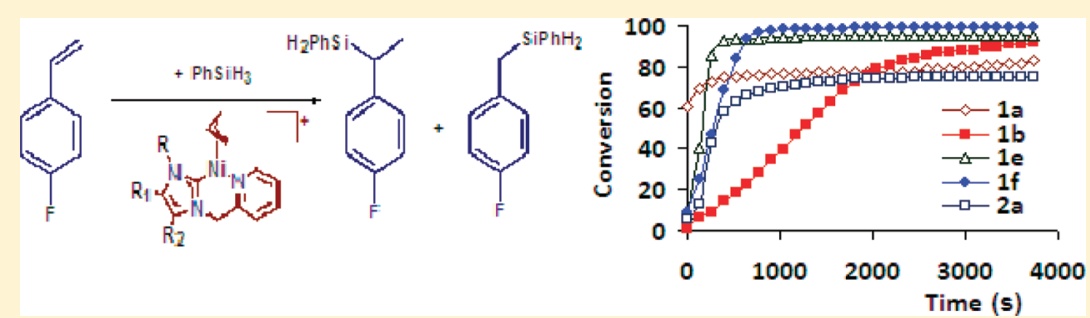

ABSTRACT: The N-heterocyclic carbene (NHC) nickel complexes $[(\mathrm{L}) \mathrm{Ni}(\mathrm{NHC})]\left[\mathrm{BAr}_{4}^{\mathrm{F}}\right]\left(\mathrm{Ar}^{\mathrm{F}}=3,5\right.$-bis $($ trifluoromethyl)phenyl; L = allyl (1), methylallyl (2); NHC = 1-(2-picolyl)-3-methylimidazol-2-ylidene (a), 1-(2-picolyl)-3-isopropylimidazol-2ylidene (b), 1-(2-picolyl)-3-n-butylimidazol-2-ylidene (c), 1-(2-picolyl)-3-phenylimidazol-2-ylidene (d), 1-(2-picolyl)-3methylbenzoimidazol-2-ylidene (e), 1-(2-picolyl)-4,5-dichloro-3-methylimidazol-2-ylidene (f)) have been obtained in high yields and characterized by NMR spectroscopy. Furthermore, 1d was unambiguously characterized by single-crystal X-ray crystallography. Complexes $\mathbf{1} \mathbf{a}-\mathbf{f} / \mathbf{2} \mathbf{a}-\mathbf{f}$ have shown catalytic activity toward dimerization and hydrosilylation of styrenes. In particular, la proved to be the most efficient catalyst in the dimerization of styrene derivatives in the absence of cocatalyst. Also, complexes 1a,d showed high selectivity and moderate to good yields in hydrosilylation reactions.

\section{INTRODUCTION}

The synthesis and isolation of the first N-heterocyclic carbene (NHC) were reported by Wanzlick, ${ }^{1,2}$ but until $1991^{3}$ NHCs did not experience a remarkable development. Since then, NHCs have became an important class of ligands in organometallic chemistry and catalysis. ${ }^{4}$

These ligands are often compared to tertiary phosphines because of the similarities in their bonding with transition metals, and in many cases, they have successfully replaced them as auxiliary ligands. However, substantial differences do exist, especially regarding their electron-donating ability. In general, NHCs are stronger Lewis bases and have a reduced $\pi$ back-bonding capability in comparison to tertiary phosphines. ${ }^{5}$ NHCs show superior performances in many aspects, including higher versatility, easier preparation, thermal, air, and moisture stability, and lower toxicity. Consequently, complexes that incorporate these ligands are more stable toward dissociative and degradative cleavage. The applications of organometallic complexes bearing NHC ligands in catalysis are now well recognized. ${ }^{3,4}$

The use of nickel NHC complexes in catalysis has been eclipsed by the far wider range of applications found for their palladium and ruthenium analogues. ${ }^{4}$ However, in the past decade several $\mathrm{NHC}-\mathrm{Ni}(0)$ and $\mathrm{NHC}-\mathrm{Ni}(\mathrm{II})$ systems have been reported. $\mathrm{NHC}-\mathrm{Ni}(0)$ complexes have emerged as efficient catalysts in $\mathrm{C}-\mathrm{S}$ couplings, ${ }^{6}[2+2+2]$ cycloadditions, $^{7-9}$ and amination of aryl chlorides. ${ }^{10}$ Nevertheless, they are very air sensitive, and their reactions usually require the use of a cocatalyst. ${ }^{11,12}$ On the other hand, NHC-Ni(II) complexes bearing electron-rich ligands have been synthesized to avoid the use of cocatalyst, and they have shown activity in $\mathrm{C}-\mathrm{C}$ cross-coupling reactions, ${ }^{11,13}$ polymerization of styrene, ${ }^{12}$ amination of aryl halides, ${ }^{14}$ and Suzuki ${ }^{15,16}$ and Kumada reactions. ${ }^{17}$

The first $\mathrm{Ni}($ allyl)-NHC complexes were reported by the groups of Sigman et al., ${ }^{18}$ Gomes, ${ }^{19}$ and Cámpora. ${ }^{20}$ Complexes of the type $\mathrm{Ni}($ allyl $)(\mathrm{X})(\mathrm{NHC})(\mathrm{X}=\mathrm{Cl}, \mathrm{Br})$ have shown activity in several $\mathrm{C}-\mathrm{C}$ coupling reactions. ${ }^{14 \mathrm{~b}, 20,21}$ In particular, polymerization reactions are very important, considering the industrial application of the resulting polymers. These reactions have been performed using nickel complexes with MAO (methylalumoxane) as cocatalyst. ${ }^{22}$ However, the application of $\mathrm{Ni}($ allyl)-NHC complexes in polymerization has been quite limited. Decomposition of the catalyst due to the cleavage of the $\mathrm{Ni}-\mathrm{NHC}$ bond, leading to the reductive elimination of the active species, ${ }^{7 \mathrm{a}, 23}$ has been proposed to explain the low activity of such complexes. This behavior has mainly been observed in cationic complexes. ${ }^{24}$

Recently, this problem has been avoided by the use of functionalized NHCs, which may act as bidentate ligands due to the presence of additional donor atoms $(\mathrm{N}, \mathrm{S}, \mathrm{O})$ in the NHC side chains. ${ }^{25}$ The hemilabile character of these groups allows additional stabilization of the resulting complexes, whereas they maintain the catalytic activity due to the possibility of

Received: October 6, 2011

Published: March 5, 2012 
developing a vacant site. On the other hand, the base-promoted $\mathrm{C}-\mathrm{H}$ activation of a labile acetonitrile ligand on a nickel-NHC center has been recently described. ${ }^{26,27}$ An appropriate design of the NHC ligand may also allow tuning of the electronic and steric properties of the ligand. ${ }^{10,28}$

We have previously reported the synthesis and reactivity of allyl-Ni(II) complexes bearing phosphines as auxiliary ligands, and they have shown great activity in alkene polymerization. ${ }^{29}$ In this paper, we extend previous studies synthesizing a series of $[(\mathrm{L}) \mathrm{Ni}(\mathrm{NHC})]^{+}(\mathrm{L}=$ allyl, methylallyl; NHC $=1$-(2-picolyl $)-$ 3-(R)-imidazol-2-ylidene ( $\mathrm{R}=\mathrm{Me}, \mathrm{iPr}, \mathrm{nBu}, \mathrm{Ph}), 1$-(2-picolyl)3-methylbenzoimidazol-2-ylidene, 1-(2-picolyl)-4,5-dichloro-3methylimidazolylidene) complexes $(\mathbf{1} \mathbf{a}-\mathbf{f} / \mathbf{2} \mathbf{a}-\mathbf{f})$, reporting the high-yield synthesis of new $\mathrm{NHC}-\mathrm{Ni}$ (II) complexes and their activity toward styrene polymerization. The wide range of picolyl-NHCs used allowed us to tune the steric and electronic properties of these new $\mathrm{Ni}$ complexes and assess the effect on the catalytic activity toward polymerization and hydrosilylation reactions of styrenes. The structure of $\left[\left(\mathrm{CH}_{2} \mathrm{CHCH}_{2}\right) \mathrm{Ni}(1-(2-\right.$ picolyl)-3-phenylimidazol-2-ylidene $)]\left[\mathrm{BAr}_{4}{ }^{\mathrm{F}}\right]$ has been determined by single-crystal $\mathrm{X}$-ray diffraction.

\section{RESULTS AND DISCUSSION}

Synthesis and Characterization of $\mathrm{Ni}(\mathrm{II})-\mathrm{NHC}$ Complexes. 2-Picolylimidazolium salts constitute a family of bidentate NHC ligands easily accessible by coupling of 2-(bromomethyl)pyridine with the corresponding imidazole derivative, as described in the literature. ${ }^{24,30}$ A series of this type of ligands has been prepared bearing different substituents at the 3-, 4-, and 5positions on the imidazolium ring (see Scheme 1). Several

Scheme 1. Synthesis of R-Allyl-Ni-NHC Complexes
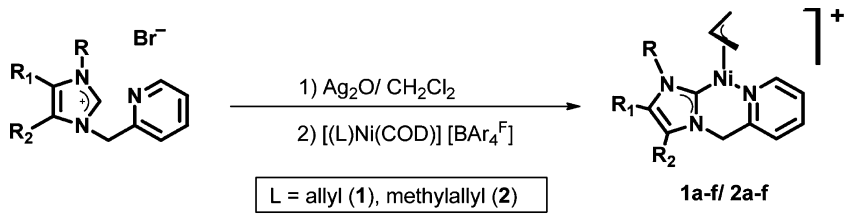

\begin{tabular}{|lll|}
\hline a $R=M e ; R_{1}=R_{2}=H$ & d $R=P h ;$ & $R_{1}=R_{2}=H$ \\
b $R={ }^{i} P r ; R_{1}=R_{2}=H$ & e $R=M e ;$ & benzoimidazolylidene \\
c $R={ }^{n} B u ; R_{1}=R_{2}=H$ & f $R=M e ;$ & $R_{1}=R_{2}=C l$ \\
\hline
\end{tabular}

methods can be used to prepare $\mathrm{Ni}(\mathrm{II})-\mathrm{NHC}$ complexes; ${ }^{28}$ among them, transmetalation from a silver precursor has proved to be very efficient. Thus, the $\mathrm{Ni}(\mathrm{II})$ complexes $[(\mathrm{L}) \mathrm{Ni}$ $(\mathrm{NHC})]\left[\mathrm{B}(\mathrm{ArF})_{4}\right](\mathrm{L}=$ allyl $(\mathbf{1})$, methylallyl (2); $\mathrm{NHC}=1$ (2-picolyl)-3-(R)-imidazol-2-ylidene $(\mathrm{R}=\mathrm{Me}(\mathbf{a}), i \operatorname{Pr}(\mathbf{b}), \mathrm{nBu}$ (c), $\mathrm{Ph}(\mathrm{d}))$, 1-(2-picolyl)-3-methylbenzoimidazol-2-ylidene (e), 1-(2-picolyl)-4,5-dichloro-3-methylimidazol-2-ylidene (f)) have been prepared by transmetalation of the corresponding silver carbenes. Silver species were generated in situ, by treatment of the appropriate 2-picolylimidazolium salt in $\mathrm{CH}_{2} \mathrm{Cl}_{2}$ with a slight excess of $\mathrm{Ag}_{2} \mathrm{O}$. The mixture was filtered through Celite. Then $[(\mathrm{L}) \mathrm{Ni}(\mathrm{COD})]\left[\mathrm{BAr}_{4} \mathrm{~F}\right](\mathrm{L}=$ allyl, methylallyl) was added to the previous mixture. After this treatment, complexes $\mathbf{1 a}-\mathbf{f}$ / $\mathbf{2 a}-\mathbf{f}$ were obtained in good yields (Scheme 1).

All of the isolated complexes lack a $\mathrm{C} 2-\mathrm{H}$ imidazolium proton signal at 10-12 ppm, indicating the coordination of the 2-picolylcarbene to the nickel atom. The ${ }^{1} \mathrm{H}$ NMR spectra of complexes $\mathbf{1 a}-\mathbf{f}$ and $\mathbf{2 a - f}$ show characteristic signals corresponding to the diastereotopic methylene protons in the $\mathrm{CH}_{2}$ bridge of the bidentate ligand, which in its coordinated form splits and appears as two $\mathrm{AB}$ doublets, with typical coupling constants for these systems $(J=14.0-15.7 \mathrm{~Hz})$, within the chemical shift range of 6.5-5.5 ppm. However not in all cases were these two signals unambiguously observed. For complexes $\mathbf{1 b}$ and $\mathbf{2 b}, \mathbf{e}$, methylene protons accidentally exhibit a broad singlet. In the case of complex le the two resonances overlap and only a doublet is observed. Complexes $\mathbf{1 f}$ and $\mathbf{2 c , f}$ show two broad singlets. All these assignments of methylene proton resonances have been confirmed by $2 \mathrm{D}$ NMR experiments. The ${ }^{13} \mathrm{C}$ NMR spectra of $\mathbf{1 a}-\mathbf{f} / \mathbf{2} \mathbf{a}-\mathbf{f}$ exhibit the resonances of the carbene carbon atoms in the distinctive interval 176-153 ppm, already observed for the carbene carbon signal of $\mathrm{Ni}-\mathrm{NHC}$ complexes. ${ }^{17 \mathrm{a}, 19,31,32}$

Crystal Structure of $\left[\mathrm{Ni}\left(\eta^{3}-\mathrm{CH}_{2} \mathrm{CHCH}_{2}\right)\left(\mathrm{NHC}-\kappa^{2} \mathrm{C}, \mathrm{N}\right)\right][\mathrm{B}-$ $\left(\mathrm{Ar}^{\mathrm{F}}\right)_{4}$ ] (1d). After recrystallization from a mixture of diethyl ether and petroleum ether, complex $\mathbf{1 d}$ was further characterized by single-crystal X-ray diffraction techniques. The ORTEP drawing of cation complex in $\mathbf{1 d}$ is displayed in Figure 1, along

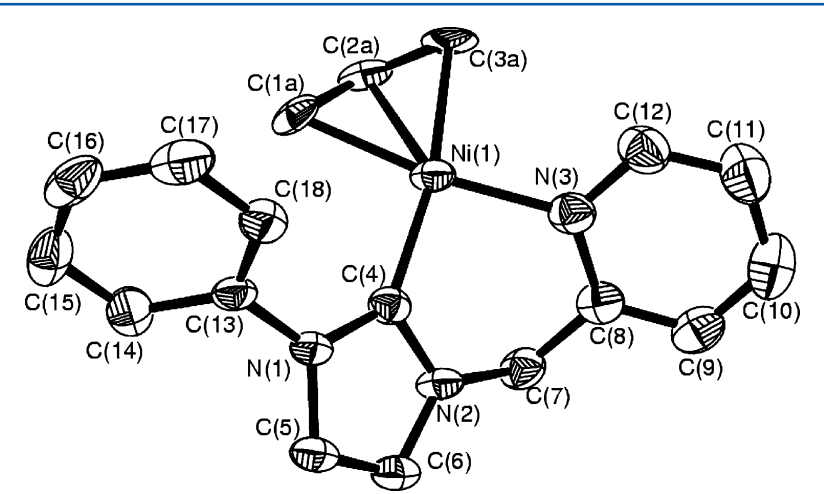

Figure 1. ORTEP view of the cation complex in $\left[\mathrm{Ni}\left(\eta^{3}-\mathrm{CH}_{2} \mathrm{CHCH}_{2}\right)\right.$ $\left.\left(\mathrm{NHC}-\kappa^{2} \mathrm{C}, \mathrm{N}\right)\right]\left[\mathrm{B}\left(\mathrm{Ar}^{\mathrm{F}}\right)_{4}\right](\mathbf{1 d}$; NHC = 1-(2-picolyl)-3-phenylimidazolylidene). Thermal ellipsoids are drawn at the $50 \%$ probability level. Hydrogen atoms have been omitted for clarity. The allyl ligand is represented only in its major orientation $(71 \%)$. Selected bond lengths $(\AA)$ and angles $(\mathrm{deg}): \mathrm{Ni}(1)-\mathrm{C}(1 \mathrm{a})=2.049(15), \mathrm{Ni}(1)-\mathrm{C}(2 \mathrm{a})=$ 2.003(8), Ni(1)-C(3a) = 1.95(2), Ni(1)-C(4) = 1.892(5), Ni(1)$\mathrm{N}(3)=1.946(5), \mathrm{C}(1 \mathrm{a})-\mathrm{C}(2 \mathrm{a})=1.432(17), \mathrm{C}(2 \mathrm{a})-\mathrm{C}(3 \mathrm{a})=$ $1.35(4) ; \mathrm{C}(4)-\mathrm{Ni}(1)-\mathrm{N}(3)=92.4(2), \mathrm{C}(1 \mathrm{a})-\mathrm{C}(2 \mathrm{a})-\mathrm{C}(3 \mathrm{a})=$ 116.9(17). Dihedral angle (deg) between planes $\mathrm{C}(1 \mathrm{a})-\mathrm{C}(2 \mathrm{a})-$ $\mathrm{C}(3 \mathrm{a})$ and $\mathrm{C}(4)-\mathrm{Ni}(1)-\mathrm{N}(3): 68.6(10)$.

with selected bond lengths and angles. The cation exhibits a classic pseudo-square-planar geometry characteristic of $\mathrm{d}^{8} \mathrm{M}$ (II) allyl complexes. The allyl ligand coordinates to the metal in a $\eta^{3}$ manner. As in other related nickel complexes, the structure reveals that the allyl ligand is disordered. This disorder has been modeled in two opposite orientations of this group relative to the rest of the molecule. Upon refining the occupancy factors, a population ratio of ca. 71:29 was obtained for the two orientations. For clarity, only the major position (approximately $71 \%)$ has been represented. The ligand 1-(2-picolyl)-3-phenylimidazol-2-ylidene, binding to the central nickel atom in a bidentate manner, completes the formal tetracoordination. Few structures of cationic allyl nickel complexes containing a $\kappa^{1} C$ NHC ligand have been reported. ${ }^{18-20,29}$ None of them contain a chelating $\kappa^{2} C$,E-NHC ligand. The $\mathrm{Ni}(1)-\mathrm{C}(4)$ distance of $1.892(5) \AA$ is typical for a Ni-NHC distance and compares well with $1.8780(2) \AA$ for $\left[\mathrm{Ni}\left(\eta^{3}\right.\right.$-allyl $)(\mathrm{NHC})\left(\mathrm{NCCH}_{3}\right]^{+}(\mathrm{NHC}=$ 1,3,4,5-tetramethylimidazol-2-ylidene) and 1.909(3) $\AA$ for $[\mathrm{Ni}$ $\left(\eta^{3}\right.$-allyl $\left.)(\mathrm{NHC})\left(\mathrm{NCCH}_{3}\right)\right]^{+}(\mathrm{NHC}=2,5$-bis $(2,6$-diisopropylphenyl)imidazol-2-ylidene). ${ }^{20}$ Other related neutral $\mathrm{Cp}$, 
$\mathrm{Cp}^{*}$, or indenyl nickel complexes also show similar parameters: for instance, in $\left[\mathrm{Ni}(\mathrm{Me}-\mathrm{NHC}) \mathrm{I}\left(\eta^{5}-\mathrm{C}_{5} \mathrm{Me}_{5}\right)\right],[\mathrm{Ni}(\mathrm{Me}-\mathrm{NHC}) \mathrm{I}-$ $\left.\left(\eta^{5}-\mathrm{C}_{5} \mathrm{H}_{5}\right)\right]$, and $\left[\mathrm{Ni}(\mathrm{Mes}-\mathrm{NHC}) \mathrm{Cl}\left(\eta^{5}-\mathrm{C}_{5} \mathrm{Me}_{5}\right)\right]$ the $\mathrm{Ni}-\mathrm{NHC}$ distances are $1.887(3), 1.880(4)$, and $1.906(3) \AA$, respectively. ${ }^{33}$ The dihedral angle between planes $C(1 a)-C(2 a)-C(3 a)$ and $\mathrm{C}(4)-\mathrm{Ni}(1)-\mathrm{N}(3)$ matches with the angles in other $\left[\mathrm{Ni}\left(\eta^{3}\right.\right.$ allyl) $(\mathrm{NHC})]^{+}$systems described in the literature. ${ }^{18-20}$

In neutral complexes $\left[\mathrm{NiBr}\left(\eta^{3}-\mathrm{CH}_{2} \mathrm{CHCH}_{2}\right)(\mathrm{NHC})\right]$ Gomes et al. ${ }^{19}$ attributed the weakening of the bond between the metal and the allyl atom placed trans to the NHC to a stronger donor ability of the imidazol-2-ylidene ring. In our case, despite the disorder found for the allyl ligand and consequent greater deviations in bond lengths, the pyridyl ring seems to show a greater trans influence, as indicated by the $\mathrm{Ni}(1)-\mathrm{C}(1 \mathrm{a})$ distance $(2.049(15) \AA)$ being longer than $\mathrm{Ni}(1)-$ $\mathrm{C}(3 \mathrm{a})(1.95(2) \AA)$. It is necessary to take into account this indication in relation to the possibilities of hemilability and chemical reactivity of the chelating ligand.

Catalytic Oligomerization of Styrenes. Polymerization of olefins is a very important type of $\mathrm{C}-\mathrm{C}$ bond coupling reaction, given the wide range of applications of polymers in industrial processes. ${ }^{11-13,15,16}$ Many organometallic compounds, especially those of $\mathrm{Ni}$ and $\mathrm{Pd}$, have been used as catalysts in such processes. ${ }^{25}$ However, a mixture of oligomers and polymers is often observed, due to the low selectivity of the catalysts. Our group has previously reported the oligomerization of styrene derivatives using $\mathrm{Ni}$ (II) complexes with good yields. ${ }^{29}$ However, it has been very difficult to find highly selective processes for low-molecular-weight oligomers. In this sense, to the best of our knowledge, the new $\mathrm{Ni}(\mathrm{II})-$ picolyl-NHC complexes have proved to be more active and selective toward styrene dimer synthesis than any other reported catalytic system (Scheme 2).

Scheme 2. Catalytic Dimerization of Styrene

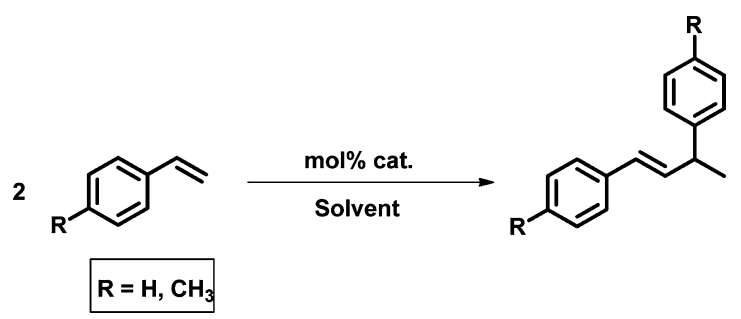

The polymerization of styrene using the catalyst $\mathbf{1 a}$ as catalyst precursor was selected as the representative reaction to optimize the system conditions. The results, given in Table 1, show that moderate to high yields were obtained at $60{ }^{\circ} \mathrm{C}$ in short reaction times (entries 14-16), especially when low catalyst loadings were used. Another result to note is that the use of a catalytic load of 1 mol \% produced the dimer with a selectivity of $100 \%$ and high yield in just $1 \mathrm{~h}$ (entry 17), while most of the systems previously reported require longer reaction times. ${ }^{29,35,36}$ Also, a noncoordinating solvent is needed to prevent solvent coordination to the metal center. ${ }^{29}$ It is important to note that, as shown in Table 1, the oligomerization of styrene proceeds with high selectivity toward dimer in all cases.

The oligomerization of styrene was carried out using compounds $\mathbf{1 a}-\mathbf{f}$ and $\mathbf{2 a}-\mathbf{f}$ to assess the effect of the ligands in the catalytic activity. As shown in Table 2, compounds $\mathbf{1 a}, \mathbf{b}$ showed the best catalytic activity, as evidenced by the high yields and selectivity of the reaction (entries 1 and 2).
Table 1. Dimerization of Styrene: Optimization of Reaction Conditions

\begin{tabular}{clcrrc} 
entry & \multicolumn{1}{c}{$T\left({ }^{\circ} \mathrm{C}\right)$} & $\begin{array}{c}\mathbf{1 a} \\
(\mathrm{mol} \%)\end{array}$ & $\begin{array}{c}t \\
(\mathrm{~h})\end{array}$ & $\begin{array}{c}\text { yield } \\
(\%)\end{array}$ & $\begin{array}{c}\text { selectivity dimer/ } \\
\text { trimer }\end{array}$ \\
1 & $40^{a}$ & 0.1 & 1 & 5 & $100 / 0$ \\
2 & $40^{a}$ & 0.1 & 2 & 6 & $100 / 0$ \\
3 & $40^{a}$ & 0.1 & 3 & 8 & $100 / 0$ \\
4 & $40^{a}$ & 0.5 & 1 & 7 & $98 / 2$ \\
5 & $40^{a}$ & 0.5 & 2 & 30 & $99 / 1$ \\
6 & $40^{a}$ & 0.5 & 3 & 42 & $90 / 10$ \\
7 & $40^{a}$ & 1 & 1 & 80 & $100 / 0$ \\
8 & $40^{a}$ & 1 & 4 & 91 & $100 / 0$ \\
9 & $40^{b}$ & 0.5 & 1 & 6 & $100 / 0$ \\
10 & $40^{b}$ & 0.5 & 2 & 25 & $100 / 0$ \\
11 & $40^{b}$ & 0.5 & 3 & 38 & $100 / 0$ \\
12 & $40^{b}$ & 1 & 1 & 76 & $100 / 0$ \\
13 & $40^{b}$ & 1 & 4 & 89 & $100 / 0$ \\
14 & $60^{b}$ & 0.5 & 1 & 63 & $100 / 0$ \\
15 & $60^{b}$ & 0.5 & 2 & 74 & $100 / 0$ \\
16 & $60^{b}$ & 0.5 & 3 & 89 & $100 / 0$ \\
17 & $6^{b}$ & $\mathbf{1}$ & $\mathbf{1}$ & $\mathbf{9 9}$ & $\mathbf{1 0 0} / 0$ \\
18 & room temp $^{a}$ & 1 & 24 & 6 & $100 / 0$ \\
19 & room temp $^{a}$ & 0.5 & 24 & 3 & $100 / 0$
\end{tabular}

${ }^{a}$ Conditions: $10 \mathrm{mmol}$ styrene, $1 \mathrm{~mL}$ of dichloroethane. ${ }^{b}$ Conditions: $1 \mathrm{~mL}$ of dichloroethane.

Table 2. Catalytic Oligomerization of Styrene

$\begin{array}{ccccc}\text { entry }^{a} & \text { cat. } & \text { yield (\%) } & \text { dimer (\%) } & \text { trimer (\%) } \\ 1^{b} & \text { 1a } & 99 & 100 & \\ 2 & \text { 1b } & 99 & 100 & \\ 3 & \text { 1c } & <5 & & \\ 4 & \text { 1d } & 70 & 100 & 33.3 \\ 5 & \text { 1e } & <5 & & 10.6 \\ 6 & \text { 1f } & 60 & 66.7 & \\ 7 & \text { 2a } & 82 & 89.4 & 13.8 \\ 8 & \text { 2b } & <5 & & \\ 9 & \text { 2c } & <5 & & \\ 10 & \text { 2d } & <5 & & \\ 11 & \text { 2e } & 53 & & \\ 12 & \text { 2f } & <5 & & \end{array}$

${ }^{a}$ Conditions: $10 \mathrm{mmol}$ of styrene, $1 \mathrm{~mL}$ of 1,2-dichloroethane at $60{ }^{\circ} \mathrm{C}$, reaction time $4 \mathrm{~h} .{ }^{b}$ Reaction time $1 \mathrm{~h}$.

However, inclusion of $\mathrm{Cl}$ or a $\mathrm{Ph}$ ring in the imidazole backbone or a phenyl substituent in the imidazole wingtip significantly decreases the reaction yields (entries 4-6). This can be rationalized by the weaker donor properties ${ }^{34}$ of the substituents on 1d,e and, in the case of 1f, the electronwithdrawing power of the $\mathrm{Cl}$ atoms. In any case, this leads to a less electron rich $\mathrm{Ni}$ (II) center that hinders the release of the allyl or Me-allyl ligand, which is necessary to complete the catalytic process according to previously published mechanism proposals. $^{29}$ On the other hand, Me-allyl-Ni(II) complexes $\mathbf{2 a}-\mathbf{f}$ showed less activity and in some cases the absence of activity in comparison with their allyl-Ni(II) counterparts 1a-f. A similar behavior has been observed for allyl-Ni and methylallyl-Ni complexes bearing the chelating phosphine ligand dippe (dippe $={ }^{i} \mathrm{Pr}_{2} \mathrm{PCH}_{2} \mathrm{CH}_{2}{ }^{i} \mathrm{Pr}_{2}$ ), as previously reported by our group. ${ }^{29}$

In addition, the oligomerization of 4-methylstyrene and $\alpha$ methylstyrene was carried out to assess the effect of the methyl 
substituent on the catalytic system. The reaction mechanism previously proposed for the polymerization of styrene indicates a strong influence of the methyl substituent, given the nature of the allyl intermediates that have to be generated to complete the reaction. ${ }^{29}$ The results, given in Table 3 , show a decreased

Table 3. Catalytic Oligomerization of 4-Methylstyrene and $\alpha$-Methylstyrene

\begin{tabular}{cccccc} 
entry $^{a}$ & cat. & olefin & yield (\%) & dimer (\%) & trimer (\%) \\
\hline 1 & 1a & 4-methylstyrene & 87 & 100 & \\
2 & 1b & 4-methylstyrene & 61 & 84.1 & 15.9 \\
3 & 1d & 4-methylstyrene & 35 & 100 & \\
4 & 1f & 4-methylstyrene & 35 & 100 & \\
5 & 2a & 4-methylstyrene & 77 & 90.9 & 9.1 \\
6 & 2e & 4-methylstyrene & 35.7 & 100 & \\
7 & 1a & $\alpha$-methylstyrene & 72 & 100 & \\
8 & 2a & $\alpha$-methylstyrene & 60 & 100 & \\
\hline
\end{tabular}

${ }^{a}$ Conditions: $10 \mathrm{mmol}$ of olefin, $1 \mathrm{~mL}$ of 1,2 -dichloroethane at $60{ }^{\circ} \mathrm{C}$, reaction time $4 \mathrm{~h}$.

activity for all the catalysts tested when 4-methylstyrene instead of styrene was used as substrate (entries $1-5$ ). In addition, the use of $\alpha$-methylstyrene diminished significantly the activity of all Ni(II)-picolyl-NHC complexes; in most cases no activity was observed. Only 1a and 2a showed catalytic activity toward oligomerization of $\alpha$-methylstyrene (entries 7 and 8). These results are in line with those previously published by our group, $^{29}$ indicating that the mechanism should be as depicted in Scheme 3, implying a very fast $\beta$-elimination step that

Scheme 3. Mechanism for Oligomerization Reaction of Styrenes

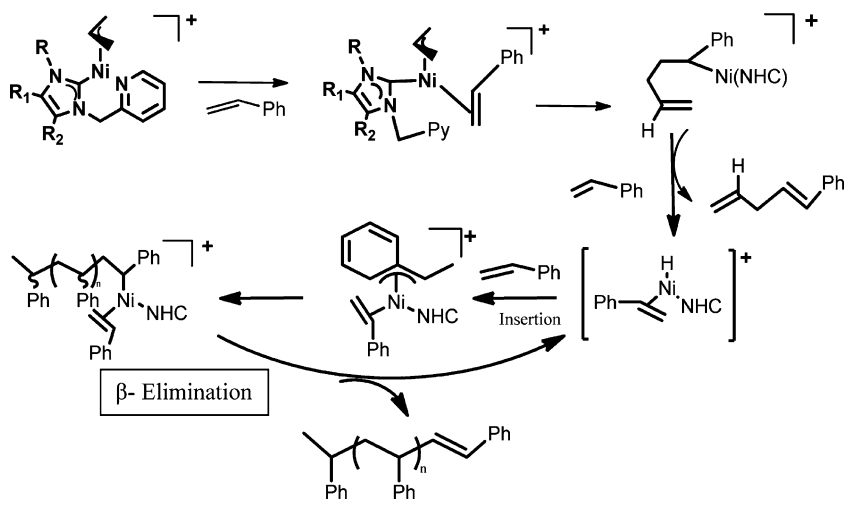

explains the high selectivity toward dimer formation. It is important to note that the structure of the $\alpha$-methylstyrene dimer is not homologous with those of the styrene or 4-methylstyrene dimers. Whereas 4-methylstyrene and styrene dimers have a head-to-tail structure, $\alpha$-methylstyrene dimer produces (4-methylpent-1-ene-2,4-diyl)dibenzene as the only structure. NMR data suggest that $\alpha$-methylstyrene dimer is produced by insertion of one $\alpha$-methylstyrene into one $\mathrm{C}-\mathrm{H}$ bond of another $\alpha$-methyl substituent. ${ }^{29}$

Catalytic Hydrosilylation of Styrenes. Catalytic hydrosilylation of alkenes is one of the most versatile and efficient methods for the synthesis of alkylsilanes and the preparation of organosilicon compounds on an industrial scale. ${ }^{35}$ For this reason, it has been widely investigated using several catalytic systems. $^{29,35}$ The conventionally accepted mechanism for this reaction includes oxidative addition of substituted silane to a metal-alkene intermediate complex, followed by migratory insertion into a $\mathrm{M}-\mathrm{H}$ bond and reductive elimination by $\mathrm{Si}-\mathrm{C}$ bond formation, regenerating the metal-alkene complex. An alternative pathway goes preferentially through an alkene insertion into the $\mathrm{M}-\mathrm{Si}$ bond. In each case a different metal-hydrido complex is involved.

The addition of $\mathrm{Si}-\mathrm{H}$ bonds across the $\mathrm{C}=\mathrm{C}$ double bond can give a mixture of products that follow Markovnikov or antiMarkovnikov rules. This reaction has been already studied by our group $^{29}$ and the Zargarian group ${ }^{35 a, b}$ using nickel(II) complexes bearing phosphine ligands as catalysts. Hence, Rallyl-Ni-NHC complexes $(\mathbf{1} \mathbf{a}-\mathbf{f} / \mathbf{2} \mathbf{a}-\mathbf{f})$ have been tested in the catalytic hydrosilylation of styrenes (Scheme 4 ).

As previously stated for the polymerization reactions, our aim has been to study the effect in the catalytic system caused by several substituents on the NHC and the allyl ligand of the $\mathrm{Ni}$ complexes. Each catalytic run has been carried out at $60{ }^{\circ} \mathrm{C}$ with $\mathrm{Ni} / \mathrm{R}$-styrene $/ \mathrm{PhSiH}_{3}$ ratios of $1 / 100 / 200$, using an excess of $\mathrm{PhSiH}_{3}$ to prevent oligomerization. Under these conditions, the hydrosilylation product isolated upon purification was either $\mathrm{RC}_{6} \mathrm{H}_{4} \mathrm{C}\left(\mathrm{R}^{\prime}\right)\left(\mathrm{CH}_{3}\right) \mathrm{SiH}_{2} \mathrm{C}_{6} \mathrm{H}_{5}$ (A) or $\mathrm{RC}_{6} \mathrm{H}_{4} \mathrm{CH}\left(\mathrm{R}^{\prime}\right)$ $\mathrm{CH}_{2} \mathrm{SiH}_{2} \mathrm{C}_{6} \mathrm{H}_{5}$ (B). Nevertheless, $\mathbf{A}$ was obtained as the major product in all cases. As shown in Table 4, compounds 1a,d were highly selective toward product $\mathbf{A}$ when styrene and 4methylstyrene were used as substrates (entries 1, 3, 10, and 12). However, $\mathbf{1} \mathbf{b}$ showed high selectivity in the styrene reaction but lost its reactivity when 4-methylstyrene was used (entries 2 and 11). On the other hand, 1e showed an opposite behavior in comparison with $\mathbf{1 b}$. Compounds $\mathbf{2} \mathbf{a}-\mathbf{f}$ gave higher yields than their allyl analogues $\mathbf{1 a}-\mathbf{f}$ but proved to be less selective in all cases. Furthermore, only $\mathbf{2 d}$,e showed activity when $\alpha$-methylstyrene was used as substrate, but low yields were obtained. However, in these cases, B was observed as the only product, showing an inversion in the selectivity pattern presented by the other substrates. Also, trisubstituted silanes such as $(\mathrm{OEt})_{3} \mathrm{SiH}$ and $\mathrm{PhMe}_{2} \mathrm{SiH}$ were tested, but none of them showed activity in the hydrosilylation of styrene.

Furthermore, in order to obtain information regarding the reaction mechanism, the hydrosilylation of three fluorosubstituted styrenes ( $\mathrm{F}$ at the 2-, 3-, or 4-position of the phenyl ring) was monitored by ${ }^{19} \mathrm{~F}$ NMR and ${ }^{1} \mathrm{H}$ NMR. The experiments

Scheme 4. Catalytic Hydrosilylation of Styrenes

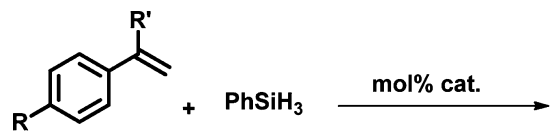

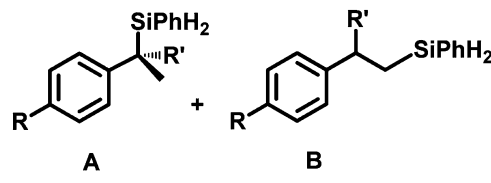


Table 4. Catalytic Hydrosilylation of Styrenes with $\mathrm{PhSiH}_{3}$

\begin{tabular}{|c|c|c|c|c|c|}
\hline entry & cat. & olefin & $\begin{array}{l}\text { yield } \\
(\%)\end{array}$ & $\begin{array}{l}\text { A: } \\
\text { Markovnikov } \\
\text { product (\%) }\end{array}$ & $\begin{array}{c}\text { B: anti- } \\
\text { Markovnikov } \\
\text { product (\%) }\end{array}$ \\
\hline 1 & 1a & styrene & 40 & 92.5 & 7.5 \\
\hline 2 & $1 b$ & styrene & 65 & 96 & 4 \\
\hline 3 & $1 d$ & styrene & 60 & 96.7 & 3.3 \\
\hline 4 & le & styrene & 90.6 & 65.1 & 34.9 \\
\hline 5 & If & styrene & 90 & 62.8 & 37.2 \\
\hline 6 & $2 a$ & styrene & 79 & 80.1 & 19.9 \\
\hline 7 & $2 d$ & styrene & 100 & 85.3 & 14.7 \\
\hline 8 & $2 \mathrm{e}$ & styrene & 90 & 53.8 & 46.2 \\
\hline 9 & $2 f$ & styrene & 100 & 60.8 & 39.2 \\
\hline 10 & 1a & 4- & 60 & 96.7 & 3.3 \\
\hline 11 & $1 b$ & $\begin{array}{l}\text { 4- } \\
\text { methylstyrene }\end{array}$ & 53 & 71.1 & 28.3 \\
\hline 12 & 1d & 4- & 60 & 95 & 5 \\
\hline 13 & $1 \mathrm{e}$ & $\begin{array}{l}\text { 4- } \\
\text { methylstyrene }\end{array}$ & 60 & 93.3 & 6.7 \\
\hline 14 & If & $\begin{array}{l}\text { 4- } \\
\text { methylstyrene }\end{array}$ & 90 & 57.3 & 42.7 \\
\hline 15 & $2 a$ & 4- & 88.5 & 73.1 & 26.9 \\
\hline 16 & $2 d$ & 4- & 100 & 76.7 & 23.3 \\
\hline 17 & $2 \mathrm{e}$ & 4- & 100 & 76.7 & 23.3 \\
\hline 18 & $2 f$ & $\begin{array}{l}\text { 4- } \\
\text { methylstyrene }\end{array}$ & 100 & 54.4 & 45.6 \\
\hline 19 & $2 d$ & $\begin{array}{l}\alpha \text { - } \\
\text { methylstyrene }\end{array}$ & 13 & & 100 \\
\hline 20 & $2 \mathrm{e}$ & $\begin{array}{l}\alpha \text { - } \\
\text { methylstyrene }\end{array}$ & 33 & & 100 \\
\hline
\end{tabular}

were carried out with fluorostyrene $(1 \mathrm{mmol})$ and $\mathrm{PhSiH}_{3}$ (1.3 mmol) using three sets of reaction conditions: (I) $1 \mathrm{~mol} \%$ of catalyst at $25{ }^{\circ} \mathrm{C}$, (II) $0.5 \mathrm{~mol} \%$ of catalyst at $60{ }^{\circ} \mathrm{C}$, and (III) $1 \mathrm{~mol} \%$ of catalyst at $60{ }^{\circ} \mathrm{C}$. Among these experiments, those including $1 \mathrm{e}$ as catalyst and 2-fluorostyrene and 4-fluorostyrene as substrates were chosen to rationalize the experimental observations (see the Supporting Information for more details). As shown in Figure 2, when the different sets of

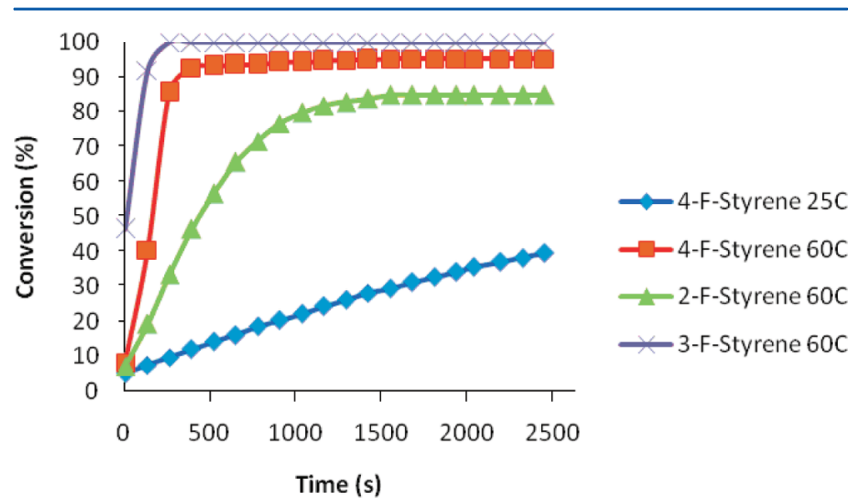

Figure 2. Hydrosilylation of fluorostyrenes with $1 \mathrm{~mol} \%$ of $\mathbf{1 e}$.

conditions are compared, it is clear that at $60{ }^{\circ} \mathrm{C}$ the reaction occurs within minutes. However, at room temperature a lower reaction rate was observed and lower conversions were obtained.

The fast conversion of 2-fluorostyrene in 1-(2-fluorophenyl)ethyl)diphenylsilane (A) can be observed in Figure 3. Also, it is important to note that the main signals in the ${ }^{19} \mathrm{~F}$ NMR spectrum at $-119.7,-121.2$, and $-121.6 \mathrm{ppm}$ are from the major reaction product $\mathrm{FC}_{6} \mathrm{H}_{4} \mathrm{CH}\left(\mathrm{CH}_{3}\right) \mathrm{SiH}_{2} \mathrm{C}_{6} \mathrm{H}_{5}$ (A), 2 -fluorostyrene, and the minor reaction product $\mathrm{FC}_{6} \mathrm{H}_{4} \mathrm{CH}_{2} \mathrm{CH}_{2} \mathrm{SiH}_{2} \mathrm{C}_{6} \mathrm{H}_{5}$ (B), respectively. However, a fourth signal in the ${ }^{19} \mathrm{~F}$ NMR spectrum at $-122.1 \mathrm{ppm}$ is observed that may correspond to a catalytically active species. In addition, the ${ }^{1} \mathrm{H}$ NMR of the reaction (Figure 4) clearly showed distinctive signals in the metal-hydride region at -29.28 and $-29.29 \mathrm{ppm}$, indicating the presence of $\mathrm{Ni}-\mathrm{H}$ intermediates. These experimental data are consistent with the participation of nickel-silyl and a nickel-hydride intermediates, as suggested by Zargarian et al. ${ }^{35}$ However, these data are insufficient to support a complete mechanistic proposal. They also illustrate that, as a result of the weakening of the double bond in the fluorinated styrenes, the hydrosilylation processes are faster in comparison with those for the non-fluorinated analogues.

\section{CONCLUSION}

We have reported the synthesis of novel allyl-and methylallylnickel complexes bearing hemilabile picolyl-NHC carbene ligands using the transmetalation method from silver precursors. These compounds have proved to be catalytically active toward dimerization of styrenes without the use of any cocatalyst, especially 1a. The dimerization reactions were highly selective toward styrene dimers and occurred with moderate to good yields. Also, the new nickel compounds showed activity in hydrosilylation reactions of styrenes. The silylated products were mainly the Markovnikov addition products when styrene and 4-methylstyrene were used but anti-Markovnikov products when $\alpha$-methylstyrene was the chosen substrate. The use of ${ }^{19} \mathrm{~F}$ NMR and ${ }^{1} \mathrm{H}$ NMR with fluorinated substrates allowed us to observe some reaction intermediates, and we propose that the possible reaction mechanism is similar to that previously reported by Zargarian. ${ }^{35}$ These catalysts have the potential to be active in other reactions, and further studies are underway.

\section{EXPERIMENTAL SECTION}

General Procedures. All reactions were performed under a dry nitrogen or argon atmosphere using standard Schlenk techniques. Dry and oxygen-free solvents were always used unless otherwise stated. The starting materials $\mathrm{Ni}(\mathrm{COD})_{2},{ }^{37}[$ allyl-Ni(COD $\left.)\right]\left[\mathrm{BAr}_{4}{ }^{\mathrm{F}}\right],{ }^{38}[\mathrm{Me}-$ allyl-Ni(COD)] $\left[\mathrm{BAr}_{4}^{\mathrm{F}}{ }^{3}\right]^{38}$ 1-methyl-3-(2-picolyl)imidazolium bromide (a) ${ }^{24}$ 1-isopropyl-3-(2-picolyl)imidazolium bromide (b), ${ }^{30 a}$ 1-butyl-3(2-picolyl)imidazolium bromide (c), ${ }^{30 a}$ 1-phenyl-3-(2-picolyl)imidazolium bromide (d), ${ }^{34}$ 1-methyl)-3-(2-picolyl)benzoimidazolium bromide (e), ${ }^{30 \mathrm{~b}}$ and 1-methyl-3-(2-picolyl)-4,5-dichloroimidazolium bromide $(\mathbf{f})^{34}$ were prepared according to the literature methods. NMR spectra were recorded using Varian INOVA 600 and $400 \mathrm{MHz}$ spectrometers. Chemical shifts are given in ppm from TMS $\left({ }^{1} \mathrm{H}\right.$ and $\left.{ }^{13} \mathrm{C}\left\{{ }^{1} \mathrm{H}\right\}\right)$ and $J$ values in $\mathrm{Hz}$; NMR signal assignments were confirmed by $2 \mathrm{D}$ NMR experiments. Microanalysis was performed on a LECO CHNS-932 elemental analyzer at the Servicio Central de Ciencia y Tecnología, Universidad de Cádiz. The GC/MS analyses of the catalytic mixtures were performed using an Agilent $6890 \mathrm{~N}$ system.

Preparation of Allyl-Nickel Complexes 1a-f. Imidazolium salts of the ligands $\mathbf{a}-\mathbf{f}(1.0 \mathrm{mmol})$ and silver oxide $(0.12 \mathrm{~g}, 0.5 \mathrm{mmol})$ were stirred in dichloromethane $(25 \mathrm{~mL})$ at room temperature for $3 \mathrm{~h}$. The resulting mixture was then filtered through Celite. [(allyl) $\mathrm{Ni}(\mathrm{COD})]$ $\left[\mathrm{BAr}_{4}{ }^{\mathrm{F}}\right](0.91 \mathrm{~g}, 0.85 \mathrm{mmol})$ was added to the solution, and the mixture was stirred at room temperature for $3 \mathrm{~h}$. After removal of the formed silver halide by filtration through Celite, the solvent was evaporated under vacuum. The residual orange-brown oil was washed with petroleum ether and dried under vacuum to give an orange-brown solid. 


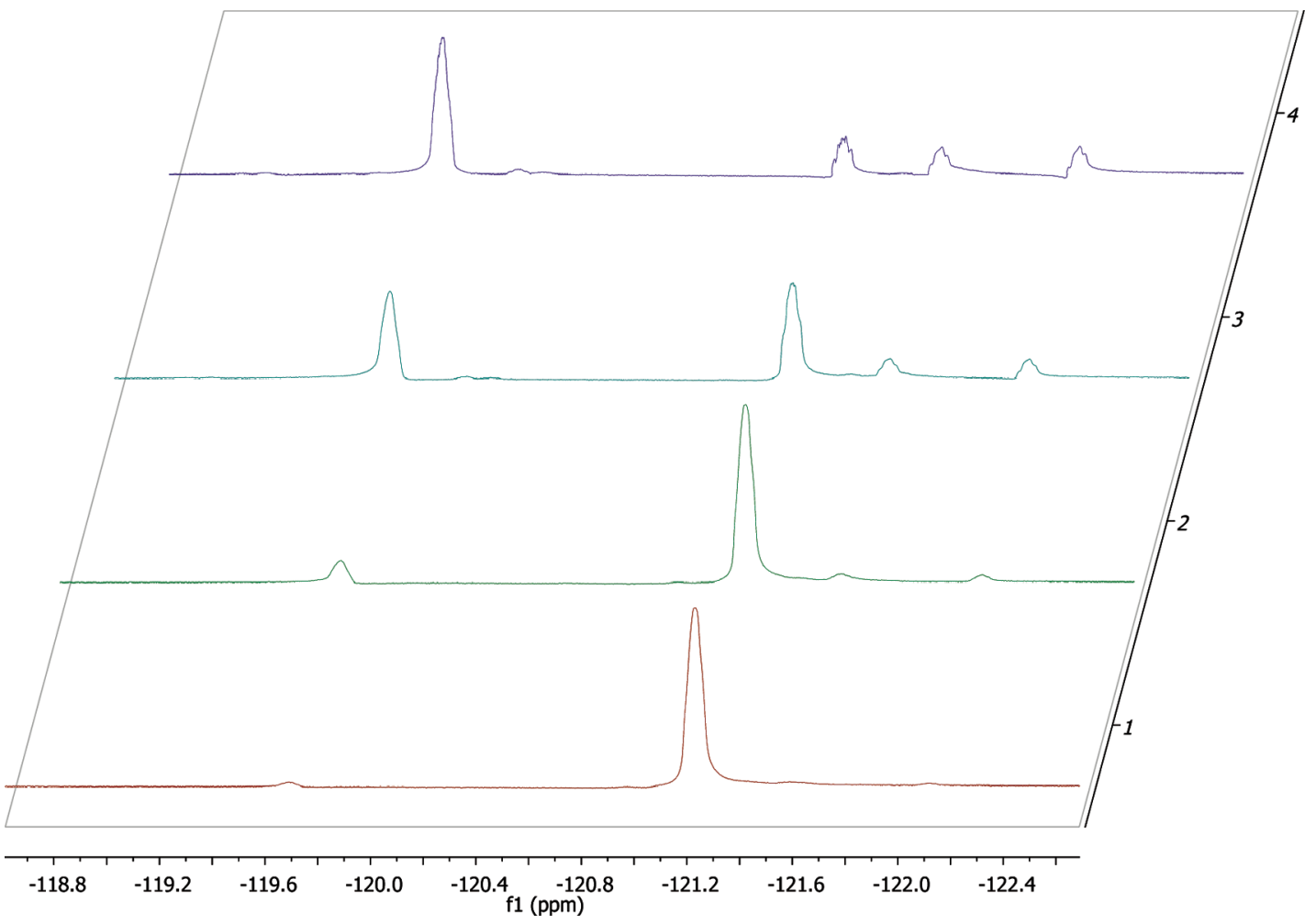

Figure 3. ${ }^{19} \mathrm{~F}$ NMR spectra $\left(\mathrm{C}_{6} \mathrm{D}_{6}, 60{ }^{\circ} \mathrm{C}\right)$ with $1 \mathrm{mmol}$ of 2-fluorostyrene, $1.3 \mathrm{mmol}$ of $\mathrm{PhSiH}_{3}$, and $1 \mathrm{~mol} \%$ of 1e: (1) $0.13 \mathrm{~min}$; (2) $2.28 \mathrm{~min}$; (3) $6.56 \mathrm{~min}$; (4) $12.68 \mathrm{~min}$.

$\left[\mathrm{Ni}\left(\eta^{3}-\mathrm{CH}_{2} \mathrm{CHCH}_{2}\right)\left(\mathrm{NHC}-\kappa^{2} \mathrm{C}, \mathrm{N}\right)\right]\left[\mathrm{B}\left(\mathrm{Ar}^{\mathrm{F}}\right)_{4}\right](1 \mathrm{a})$. Yield: $0.67 \mathrm{~g}, 70 \%$. ${ }^{1} \mathrm{H}$ NMR (acetone- $\left.d_{6}, 298 \mathrm{~K}\right): \delta 9.022\left(\mathrm{~d}, 1 \mathrm{H},{ }^{3} J_{\mathrm{H}-\mathrm{H}}=5.28,1 \mathrm{H}_{\mathrm{py}}\right.$ ), $8.091\left(\mathrm{vt}, 1 \mathrm{H},{ }^{3} J_{\mathrm{H}-\mathrm{H}}=5.28, \mathrm{~J}_{\mathrm{H}-\mathrm{H}}=1.46,1 \mathrm{H}_{\mathrm{py}}\right), 7.875\left(\mathrm{~d}, 1 \mathrm{H},{ }^{3} J_{\mathrm{H}-\mathrm{H}}=\right.$ 7.62, $\left.1 \mathrm{H}_{\mathrm{py}}\right), 7.804\left(\mathrm{~s}, 8 \mathrm{H}, \mathrm{BAr}_{4}{ }^{\mathrm{F}}\right), 7.667\left(\mathrm{~s}, 4 \mathrm{H}, \mathrm{BAr}_{4}{ }^{\mathrm{F}}\right), 7.555(\mathrm{t}, 1 \mathrm{H}$, $\left.{ }^{3} J_{\mathrm{H}-\mathrm{H}}=7.62, J_{\mathrm{H}-\mathrm{H}}=1.46,1 \mathrm{H}_{\mathrm{py}}\right), 7.540\left(\mathrm{~d}, 1 \mathrm{H},{ }^{3} \mathrm{~J}_{\mathrm{H}-\mathrm{H}}=1.76,1 \mathrm{H}_{\mathrm{Im}}\right)$, $7.307\left(\mathrm{~d}, 1 \mathrm{H},{ }^{3} J_{\mathrm{H}-\mathrm{H}}=1.76,1 \mathrm{H}_{\mathrm{Im}}\right), 5.798\left(\mathrm{~d}, 1 \mathrm{H},{ }^{2} \mathrm{~J}_{\mathrm{H}-\mathrm{H}}=14.94\right.$, $\mathrm{CH}_{2}$ bridge $), 5.798\left(\mathrm{q}, 1 \mathrm{H}, 1 \mathrm{H}_{\text {allyl } \mathrm{CH}}\right), 5.611\left(\mathrm{~d}, 1 \mathrm{H},{ }^{2} J_{\mathrm{H}-\mathrm{H}}=14.94\right.$, $\mathrm{CH}_{2}$ bridge $) ; 3.882\left(\mathrm{~s}, 3 \mathrm{H}, \mathrm{CH}_{3}\right), 3.849\left(\mathrm{~d}, 1 \mathrm{H},{ }^{3} J_{\mathrm{H}-\mathrm{H}}=2.34,1 \mathrm{H}_{\text {allyl }}\right)$, $3.513\left(\mathrm{~d}, 1 \mathrm{H},{ }^{3} J_{\mathrm{H}-\mathrm{H}}=7.04,1 \mathrm{H}_{\text {allyl }}\right), 3.241\left(\mathrm{~d}, 1 \mathrm{H},{ }^{3} J_{\mathrm{H}-\mathrm{H}}=14.35\right.$, $\left.1 \mathrm{H}_{\text {allyy }}\right), 2.504\left(\mathrm{~d}, 1 \mathrm{H},{ }^{3} \mathrm{~J}_{\mathrm{H}-\mathrm{H}}=13.19,1 \mathrm{H}_{\text {allyl }}\right) .{ }^{13} \mathrm{C}\left\{{ }^{1} \mathrm{H}\right\}$ NMR (acetone$\left.d_{6}, 298 \mathrm{~K}\right): \delta 176.05\left(\mathrm{C}_{\mathrm{Im}}\right), 162.54\left(\mathrm{BAr}_{4}{ }^{\mathrm{F}}\right), 155.49\left(\mathrm{C}_{\mathrm{py}}\right), 155.29$ $\left(\mathrm{C}_{\text {ipso }}\right), 140.38\left(\mathrm{C}_{\mathrm{py}}\right), 135.46\left(\mathrm{BAr}_{4}{ }^{\mathrm{F}}\right), 129.81\left(\mathrm{BAr}_{4}{ }^{\mathrm{F}}\right), 125.69\left(\mathrm{C}_{\mathrm{py}}\right)$, $124.78\left(\mathrm{C}_{\mathrm{Im}}\right), 124.45\left(\mathrm{C}_{\mathrm{py}}\right), 122.68\left(\mathrm{C}_{\mathrm{Im}}\right), 118.28\left(\mathrm{BAr}_{4}^{\mathrm{F}}\right), 116.81$ $\left(\mathrm{C}_{12}\right), 70.93\left(\mathrm{C}_{\text {allyl }}\right), 54.29\left(\mathrm{C}_{\mathrm{CH}_{2} \text { bridge }}\right), 48.32\left(\mathrm{C}_{\text {allyl }}\right), 37.75\left(\mathrm{C}_{\mathrm{CH}_{3}}\right)$. Anal. Calcd for $\mathrm{C}_{45} \mathrm{H}_{28} \mathrm{BF}_{24} \mathrm{~N}_{3} \mathrm{Ni}$ : C, 47.57; H, 2.48; N, 3.70. Found: C, 47.69; H, 2.54; N, 3.58.

$\left[\mathrm{Ni}\left(\eta^{3}-\mathrm{CH}_{2} \mathrm{CHCH}_{2}\right)\left(\mathrm{NHC}-\kappa^{2} \mathrm{C}, \mathrm{N}\right)\right]\left[B\left(\mathrm{Ar}^{\mathrm{F}}\right)_{4}\right]$ (1b). Yield: $0.49 \mathrm{~g}, 50 \%$. ${ }^{1} \mathrm{H}$ NMR (acetone- $\left.d_{6}, 298 \mathrm{~K}\right): \delta 8.74\left(\mathrm{~d}, 1 \mathrm{H},{ }^{3} \mathrm{~J}_{\mathrm{H}-\mathrm{H}}=5.45,1 \mathrm{H}_{\mathrm{py}}\right), 7.79$ (vt, $\left.1 \mathrm{H},{ }^{3} \mathrm{~J}_{\mathrm{H}-\mathrm{H}}=7.57,1 \mathrm{H}_{\mathrm{py}}\right), 7.62\left(\mathrm{~d}, 1 \mathrm{H},{ }^{3} \mathrm{~J}_{\mathrm{H}-\mathrm{H}}=8.03,1 \mathrm{H}_{\mathrm{py}}\right), 7.36$ (vs, $\left.1 \mathrm{H}, 1 \mathrm{H}_{\text {Im }}\right), 7.25\left(\mathrm{t}, 1 \mathrm{H},{ }^{3} J_{\mathrm{H}-\mathrm{H}}=7.76,1 \mathrm{H}_{\mathrm{py}}\right), 7.11\left(\mathrm{vs}, 1 \mathrm{H}, 1 \mathrm{H}_{\mathrm{Im}}\right.$ ), $5.45\left(\mathrm{~s}_{\text {broad }}, 2 \mathrm{H}, \mathrm{CH}_{2 \text { bridge }}\right), 5.23\left(\mathrm{~m}, 1 \mathrm{H}, 1 \mathrm{H}_{\text {allyl }}\right), 4.53\left(\mathrm{~m}, 1 \mathrm{H}, 1 \mathrm{H}_{\text {Isp }}\right)$, 1.93 (vs, $\left.1 \mathrm{H}, 1 \mathrm{H}_{\text {allyl }}\right), 1.33$ (vs, $\left.1 \mathrm{H}, 1 \mathrm{H}_{\text {allyl }}\right), 1.20\left(\mathrm{~s}, 6 \mathrm{H}, 2 \times \mathrm{CH}_{3 \text { Isp }}\right)$, 0.58 (vs, $\left.1 \mathrm{H}, 1 \mathrm{H}_{\text {allyl }}\right) ; 0.57$ (vs, $1 \mathrm{H}, 1 \mathrm{H}_{\text {allyl }}$ ). ${ }^{13} \mathrm{C}\left\{{ }^{1} \mathrm{H}\right\}$ NMR (acetone$\left.d_{6}, 298 \mathrm{~K}\right): \delta 175.19\left(\mathrm{C}_{\mathrm{Im}}\right), 154.84\left(\mathrm{C}_{\mathrm{py}}\right), 150.90\left(\mathrm{C}_{\mathrm{ipso}}\right), 139.74\left(\mathrm{C}_{\mathrm{py}}\right)$, $128.43\left(\mathrm{C}_{\text {allyl }}\right), 125.86\left(\mathrm{C}_{\mathrm{py}}\right), 124.72\left(\mathrm{C}_{\mathrm{py}}\right), 124.00\left(\mathrm{C}_{\mathrm{Im}}\right), 123.11$ $\left(\mathrm{C}_{\text {Im }}\right), 54.10\left(\mathrm{CH}_{2}\right.$ bridge $), 52.50\left(\mathrm{C}_{\text {Isp }}\right), 27.82\left(\mathrm{C}_{\text {allyl }}\right), 22.82\left(\mathrm{C}_{\text {Isp }}\right)$, $22.08\left(\mathrm{C}_{\text {allyy }}\right)$. Anal. Calcd for $\mathrm{C}_{47} \mathrm{H}_{32} \mathrm{BF}_{24} \mathrm{~N}_{3} \mathrm{Ni}$ : C, 48.49; H, 2.77; N, 3.61. Found: $\mathrm{C}, 48.57$; H, 2.65; N, 3.47 .

$\left[\mathrm{Ni}\left(\eta^{3}-\mathrm{CH}_{2} \mathrm{CHCH}_{2}\right)\left(\mathrm{NHC}-\kappa^{2} \mathrm{C}, \mathrm{N}\right)\right]\left[\mathrm{B}\left(\mathrm{Ar}^{\mathrm{F}}\right)_{4}\right]$ (1c). Yield: $0.40 \mathrm{~g}, 40 \%$. ${ }^{1} \mathrm{H}$ NMR (acetone- $\left.d_{6}, 298 \mathrm{~K}\right): \delta 9.19\left(\mathrm{~d}, 1 \mathrm{H},{ }^{3} J_{\mathrm{H}-\mathrm{H}}=4.4,1 \mathrm{H}_{\mathrm{py}}\right), 8.25$ (vt, $\left.1 \mathrm{H},{ }^{3} J_{\mathrm{H}-\mathrm{H}}=7.33,1 \mathrm{H}_{\mathrm{py}}\right), 8.05\left(\mathrm{~d}, 1 \mathrm{H},{ }^{3} J_{\mathrm{H}-\mathrm{H}}=7.33,1 \mathrm{H}_{\mathrm{py}}\right), 7.74(\mathrm{~s}$, $\left.1 \mathrm{H}, 1 \mathrm{H}_{\mathrm{Im}}\right), 7.72\left(\mathrm{t}, 1 \mathrm{H},{ }^{3} J_{\mathrm{H}-\mathrm{H}}=6.16,1 \mathrm{H}_{\mathrm{py}}\right), 7.55\left(\mathrm{~s}, 1 \mathrm{H}, 1 \mathrm{H}_{\mathrm{Im}}\right) 6.01$ $\left(\mathrm{d}_{\text {overlapped }}, 1 \mathrm{H}, \mathrm{CH}_{2 \text { bridge }}\right), 5.83\left(\mathrm{~d}, 1 \mathrm{H},{ }^{2} J_{\mathrm{H}-\mathrm{H}}=14.08, \mathrm{CH}_{2}\right.$ bridge $), 4.35$ $\left(\mathrm{t}, 2 \mathrm{H},{ }^{3} J_{\mathrm{H}-\mathrm{H}}=7.04, \mathrm{CH}_{2 \mathrm{Bu}}\right), 4.02\left(\mathrm{~d}, 1 \mathrm{H},{ }^{3} \mathrm{~J}_{\mathrm{H}-\mathrm{H}}=6.74,1 \mathrm{H}_{\text {allyl }}\right), 3.65$ (vs, $\left.1 \mathrm{H}, 1 \mathrm{H}_{\text {allyl }}\right), 3.46\left(\mathrm{~d}, 1 \mathrm{H},{ }^{3} \mathrm{~J}_{\mathrm{H}-\mathrm{H}}=14.08,1 \mathrm{H}_{\text {allyl }}\right), 2.62$ (vs, $1 \mathrm{H}$, $\left.1 \mathrm{H}_{\text {allyl }}\right), 1.53\left(\mathrm{~m}, 2 \mathrm{H}, \mathrm{CH}_{2 \mathrm{Bu}}\right), 1.09\left(\mathrm{t}, 3 \mathrm{H},{ }^{3} \mathrm{~J}_{\mathrm{H}-\mathrm{H}}=7.23, \mathrm{CH}_{3 \mathrm{Bu}}\right), 1.01$ (m, 2H, $\mathrm{CH}_{2 \mathrm{Bu}}$ ), ${ }^{13} \mathrm{C}\left\{{ }^{1} \mathrm{H}\right\}$ NMR (acetone- $\left.d_{6}, 298 \mathrm{~K}\right): \delta 175.87\left(\mathrm{C}_{\mathrm{Im}}\right)$, $155.49\left(\mathrm{C}_{\mathrm{py}}\right), 155.44\left(\mathrm{C}_{\mathrm{ipso}}\right), 140.43\left(\mathrm{C}_{\mathrm{py}}\right), 126.41\left(\mathrm{C}_{\mathrm{py}}\right), 125.28\left(\mathrm{C}_{\mathrm{py}}\right)$, $123.04\left(\mathrm{C}_{\mathrm{Im}}\right), 121.76\left(\mathrm{C}_{\mathrm{Im}}\right), 116.57\left(\mathrm{C}_{\text {allyl }}\right), 71.14\left(\mathrm{C}_{\text {allyy }}\right), 54.28$ $\left(\mathrm{CH}_{2}\right.$ bridge $), 47.96\left(\mathrm{C}_{\text {allyl }}\right)$. Anal. Calcd for $\mathrm{C}_{48} \mathrm{H}_{34} \mathrm{BF}_{24} \mathrm{~N}_{3} \mathrm{Ni}$ : C, 48.93; $\mathrm{H}, 2.91$; N, 3.57. Found: C, 48.81; H, 3.00; N, 3.49.

$\left[\mathrm{Ni}\left(\eta^{3}-\mathrm{CH}_{2} \mathrm{CHCH}_{2}\right)\left(\mathrm{NHC}-\kappa^{2} \mathrm{C}, \mathrm{N}\right)\right]\left[\mathrm{B}\left(\mathrm{Ar}^{\mathrm{F}}\right)_{4}\right]$ (1d). Yield: $0.61 \mathrm{~g}, 60 \%$. ${ }^{1} \mathrm{H}$ NMR (acetone- $\left.d_{6}, 298 \mathrm{~K}\right): \delta 9.167\left(\mathrm{~d}, 1 \mathrm{H},{ }^{3} \mathrm{~J}_{\mathrm{H}-\mathrm{H}}=4.68,1 \mathrm{H}_{\mathrm{py}}\right.$ ), $8.129\left(\mathrm{t}, 1 \mathrm{H},{ }^{3} \mathrm{~J}_{\mathrm{H}-\mathrm{H}}=7.03,1 \mathrm{H}_{\mathrm{py}}\right), 8.004\left(\mathrm{~d}, 1 \mathrm{H},{ }^{3} \mathrm{~J}_{\mathrm{H}-\mathrm{H}}=7.91,1 \mathrm{H}_{\mathrm{py}}\right)$, overlapped with the $\mathrm{BAr}_{4}{ }^{\mathrm{F}}\left(2 \times 1 \mathrm{H}_{\mathrm{Im}}\right), 7.574\left(\mathrm{vt}, 1 \mathrm{H},{ }^{3} \mathrm{~J}_{\mathrm{H}-\mathrm{H}}=7.61\right.$, $\left.1 \mathrm{H}_{\mathrm{py}}\right), 6.122\left(\mathrm{~d}, 1 \mathrm{H},{ }^{2} J_{\mathrm{H}-\mathrm{H}}=14.65, \mathrm{CH}_{2}\right.$ bridge $), 5.885\left(\mathrm{~d}, 1 \mathrm{H},{ }^{2} J_{\mathrm{H}-\mathrm{H}}=\right.$ $14.65, \mathrm{CH}_{2}$ bridge $), 5.656\left(\mathrm{q}, 1 \mathrm{H}, 1 \mathrm{H}_{\text {allyl }}\right), 3.874\left(\mathrm{~d}, 1 \mathrm{H},{ }^{3} \mathrm{~J}_{\mathrm{H}-\mathrm{H}}=7.03\right.$, $\left.1 \mathrm{H}_{\text {allyl }}\right), 3.175\left(\mathrm{~d}, 1 \mathrm{H},{ }^{3} J_{\mathrm{H}-\mathrm{H}}=14.36,1 \mathrm{H}_{\text {allyl }}\right), 2.414\left(\mathrm{~s}_{\text {broad }} 1 \mathrm{H}, 1 \mathrm{H}_{\text {allyl }}\right)$, $1.933\left(\mathrm{~d}, 1 \mathrm{H},{ }^{3} \mathrm{~J}_{\mathrm{H}-\mathrm{H}}=13.48,1 \mathrm{H}_{\text {allyl }}\right)$, phenyl group signals are between 7 and 8 ppm. ${ }^{13} \mathrm{C}\left\{{ }^{1} \mathrm{H}\right\}$ NMR (acetone- $\left.d_{6}, 298 \mathrm{~K}\right): \delta 176.40\left(\mathrm{C}_{\mathrm{Im}}\right)$, $155.05\left(\mathrm{C}_{\mathrm{py}}\right), 154.26\left(\mathrm{C}_{\mathrm{ipso}}\right), 139.71\left(\mathrm{C}_{\mathrm{py}}\right), 139.64\left(\mathrm{C}_{\mathrm{py}}\right), 124.74\left(\mathrm{C}_{\mathrm{py}}\right)$, overlapped with the $\mathrm{BAr}_{4}{ }^{\mathrm{F}}\left(\mathrm{C}_{4-\mathrm{Im}}\right)$ and $\left(\mathrm{C}_{5-\mathrm{Im}}\right), 115.52\left(\mathrm{C}_{\text {ally }}\right), 69.52$ $\left(\mathrm{C}_{\text {allyl }}\right), 53.94\left(\mathrm{CH}_{2}\right.$ bridge $), 49.22\left(\mathrm{C}_{\text {allyl }}\right)$, phenyl group signals are between 120 and $130 \mathrm{ppm}$. Anal. Calcd for $\mathrm{C}_{50} \mathrm{H}_{30} \mathrm{BF}_{24} \mathrm{~N}_{3} \mathrm{Ni}$ : C, 50.12; $\mathrm{H}, 2.52 ; \mathrm{N}, 3.51$. Found: C, 49.98; H, 2.30; N, 3.29.

$\left[\mathrm{Ni}\left(\eta^{3}-\mathrm{CH}_{2} \mathrm{CHCH}_{2}\right)\left(\mathrm{NHC}-\mathrm{k}^{2} \mathrm{C}, \mathrm{N}\right)\right]\left[\mathrm{B}\left(\mathrm{Ar}^{\mathrm{F}}\right)_{4}\right](1 \mathrm{e})$. Yield: $0.50 \mathrm{~g}, 50 \%$. ${ }^{1} \mathrm{H}$ NMR (acetone- $\left.d_{6}, 298 \mathrm{~K}\right): \delta 9.08\left(\mathrm{~d}, 1 \mathrm{H},{ }^{3} J_{\mathrm{H}-\mathrm{H}}=5.27,1 \mathrm{H}_{\mathrm{py}}\right), 8.08$ $\left(\mathrm{s}, 2 \mathrm{H}, 2 \mathrm{H}_{\text {benzo }}\right), 7.95\left(\mathrm{t}, 1 \mathrm{H},{ }^{3} J_{\mathrm{H}-\mathrm{H}}=7.62,1 \mathrm{H}_{\mathrm{py}}\right), 7.67\left(\mathrm{~d}, 1 \mathrm{H},{ }^{3} J_{\mathrm{H}-\mathrm{H}}=\right.$ 7.91, $\left.1 \mathrm{H}_{\mathrm{py}}\right), 7.57\left(\mathrm{~s}, 2 \mathrm{H}, 2 \mathrm{H}_{\text {benzo }}\right), 7.43\left(\mathrm{vt}, 1 \mathrm{H},{ }^{3} J_{\mathrm{H}-\mathrm{H}}=8.8,1 \mathrm{H}_{\mathrm{py}}\right)$, $6.097\left(\mathrm{~d}, 2 \mathrm{H},{ }^{2} J_{\mathrm{H}-\mathrm{H}}=15.66, \mathrm{CH}_{2}\right.$ bridge $), 5.954\left(\mathrm{q}, 1 \mathrm{H}, 1 \mathrm{H}_{\text {allyl }}\right), 4.53$ $\left(\mathrm{s}_{\text {broad }} 1 \mathrm{H}, 1 \mathrm{H}_{\text {allyl }}\right), 4.12\left(\mathrm{~s}, 3 \mathrm{H}, \mathrm{CH}_{3}\right), 2.30\left(\mathrm{~s}, 1 \mathrm{H}, 1 \mathrm{H}_{\text {allyl }}\right), 2.23(\mathrm{~s}, 1 \mathrm{H}$, $\left.1 \mathrm{H}_{\text {allyl }}\right), 1.46\left(\mathrm{~s}, 1 \mathrm{H}, 1 \mathrm{H}_{\text {allyl }}\right) .{ }^{13} \mathrm{C}\left\{{ }^{1} \mathrm{H}\right\}$ NMR (acetone- $\left.d_{6}, 298 \mathrm{~K}\right): \delta$ $155.03\left(\mathrm{C}_{\mathrm{py}}\right), 154.48\left(\mathrm{C}_{\text {ipso }}\right), 153.31\left(\mathrm{C}_{\mathrm{Im}}\right), 139.98\left(\mathrm{C}_{\text {benzo }}\right), 126.09$ $\left(\mathrm{C}_{\text {benzo }}\right), 124.94\left(\mathrm{C}_{\mathrm{py}}\right), 123.87\left(\mathrm{C}_{\mathrm{py}}\right), 123.40\left(\mathrm{C}_{\mathrm{Im}}\right), 120.67\left(\mathrm{C}_{\mathrm{Im}}\right)$, $111.24\left(\mathrm{C}_{\text {allyl }}\right), 110.60\left(\mathrm{C}_{\mathrm{py}}\right), 50.10\left(\mathrm{CH}_{2}\right.$ bridge $), 34.24\left(\mathrm{CH}_{3}\right), 32.09$ $\left(\mathrm{C}_{\text {allyy }}\right)$, $27.93\left(\mathrm{C}_{\text {allyl }}\right)$. Anal. Calcd for $\mathrm{C}_{49} \mathrm{H}_{30} \mathrm{BF}_{24} \mathrm{~N}_{3} \mathrm{Ni}$ : C, 49.61; H, 2.55; N, 3.54. Found: C, 49.78; H, 2.60; N, 3.48 .

$\left[\mathrm{Ni}\left(\eta^{3}-\mathrm{CH}_{2} \mathrm{CHCH}_{2}\right)\left(\mathrm{NHC}-\kappa^{2} \mathrm{C}, \mathrm{N}\right)\right]\left[\mathrm{B}\left(\mathrm{Ar}^{\mathrm{F}}\right)_{4}\right]$ (1f). Yield: $0.61 \mathrm{~g}, 60 \% .{ }^{1} \mathrm{H}$ NMR (acetone- $\left.d_{6}, 298 \mathrm{~K}\right): \delta 8.85\left(\mathrm{~d}, 1 \mathrm{H},{ }^{3} J_{\mathrm{H}-\mathrm{H}}=3.81,1 \mathrm{H}_{\mathrm{py}}\right), 7.909$ $\left(\mathrm{t}, 1 \mathrm{H},{ }^{3} J_{\mathrm{H}-\mathrm{H}}=7.33,1 \mathrm{H}_{\mathrm{py}}\right), 7.83\left(\mathrm{~d}, 1 \mathrm{H},{ }^{3} J_{\mathrm{H}-\mathrm{H}}=7.04,1 \mathrm{H}_{\mathrm{py}}\right), 7.39(\mathrm{t}$, $\left.1 \mathrm{H}, 1 \mathrm{H}_{\text {py }}\right), 5.95\left(\mathrm{~s}, 1 \mathrm{H}, \mathrm{CH}_{2}\right.$ bridge $), 5.80\left(\mathrm{~s}_{\text {broad }}, 1 \mathrm{H}, \mathrm{CH}_{2}\right.$ bridge $), 5.48$ $\left(\mathrm{m}, 1 \mathrm{H}, 1 \mathrm{H}_{\text {allyl }}\right), 3.95\left(\mathrm{vs}, 1 \mathrm{H}, 1 \mathrm{H}_{\text {allyl }}\right), 3.69\left(\mathrm{~s}, 3 \mathrm{H}, \mathrm{CH}_{3}\right), 3.36$ (vs, $1 \mathrm{H}$, 


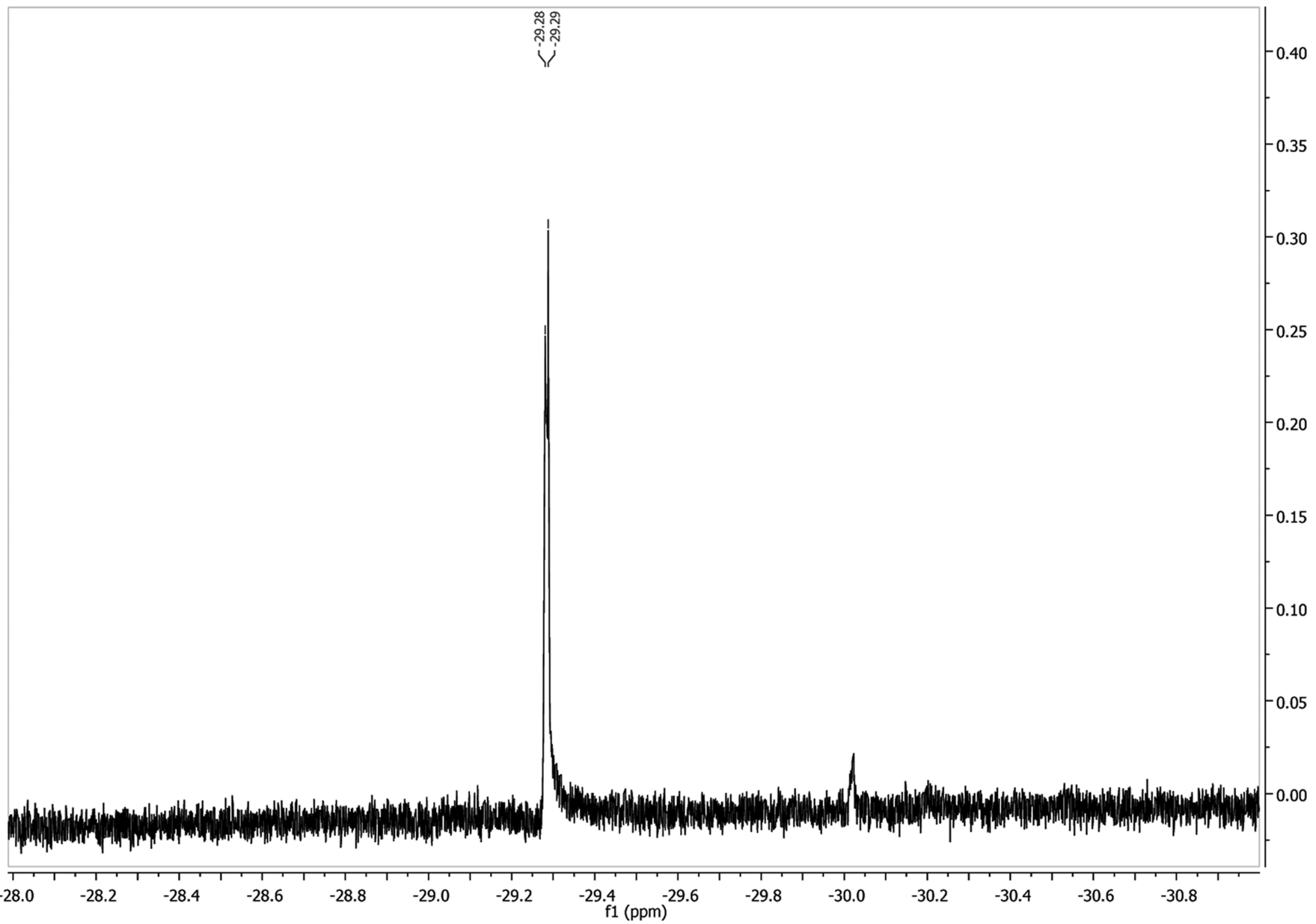

Figure 4. ${ }^{1} \mathrm{H}$ NMR spectrum after reaction of 2-fluorostyrene with $\mathrm{PhSiH}_{3}$ catalyzed by 1e.

$\left.1 \mathrm{H}_{\text {allyy }}\right), 2.38$ (vs, $1 \mathrm{H}, 1 \mathrm{H}_{\text {allyy }}$ ), 0.86 (vs, $\left.1 \mathrm{H}, 1 \mathrm{H}_{\text {allyl }}\right) \cdot{ }^{13} \mathrm{C}\left\{{ }^{1} \mathrm{H}\right\} \mathrm{NMR}$ (acetone- $\left.d_{6}, 298 \mathrm{~K}\right): \delta 155.36\left(\mathrm{C}_{\mathrm{py}}\right), 155.30\left(\mathrm{C}_{\mathrm{ipso}}\right), 153.59\left(\mathrm{C}_{\mathrm{Im}}\right)$, $139.31\left(\mathrm{C}_{\mathrm{py}}\right), 126.03\left(\mathrm{C}_{\mathrm{py}}\right), 125.32\left(\mathrm{C}_{\mathrm{py}}\right), 124.18\left(\mathrm{C}_{\mathrm{Im}}\right), 122.30\left(\mathrm{C}_{\mathrm{Im}}\right)$, $116.79\left(\mathrm{C}_{\text {allyl }}\right), 70.48\left(\mathrm{C}_{\text {allyl }}\right), 51.56\left(\mathrm{CH}_{2}\right.$ bridge $), 35.86\left(\mathrm{CH}_{3}\right), 28.23$ $\left(\mathrm{C}_{\text {allyl }}\right)$. Anal. Calcd for $\mathrm{C}_{45} \mathrm{H}_{26} \mathrm{BCl}_{2} \mathrm{~F}_{24} \mathrm{~N}_{3} \mathrm{Ni}$ : C, 44.85; H, 2.17; N, 3.49. Found: C, 45.04; H, 2.28; N, 3.38 .

Preparation of Methylallyl-Nickel Complexes 2a-f. Imidazolium salts of the ligands $\mathbf{a}-\mathbf{f}(1.0 \mathrm{mmol})$ and silver oxide $(0.12 \mathrm{~g}$, $0.5 \mathrm{mmol})$ in dichloromethane $(25 \mathrm{~mL})$ were stirred at room temperature for $3 \mathrm{~h}$. The resulting mixture was then filtered through Celite. $[\mathrm{Me}-(\mathrm{allyl}) \mathrm{Ni}(\mathrm{COD})]\left[\mathrm{BAr}_{4}{ }^{\mathrm{F}}\right](0.92 \mathrm{~g}, 0.85 \mathrm{mmol})$ was added to the solution, and the mixture was stirred at room temperature for $3 \mathrm{~h}$. After removal of the formed silver halide by filtration through Celite, the solvent was evaporated under vacuum. The residual orange-brown oil was washed with petroleum ether and dried under vacuum to give an orange-brown solid.

$\left[\mathrm{Ni}\left(\eta^{3}-\mathrm{CH}_{2} \mathrm{CCH}_{3} \mathrm{CH}_{2}\right)\left(\mathrm{NHC}-\kappa^{2} \mathrm{C}, \mathrm{N}\right)\right]\left[\mathrm{B}\left(\mathrm{Ar}^{\mathrm{F}}\right)_{4}\right](2 \mathrm{a})$. Yield: $0.64 \mathrm{~g}, 65 \%$. ${ }^{1} \mathrm{H}$ NMR (acetone- $\left.d_{6}, 298 \mathrm{~K}\right): \delta 9.030\left(\mathrm{~d}, 1 \mathrm{H},{ }^{3} \mathrm{~J}_{\mathrm{H}-\mathrm{H}}=5.12,1 \mathrm{H}_{\mathrm{py}}\right)$, $8.076\left(\mathrm{t}, 1 \mathrm{H}, J_{\mathrm{H}-\mathrm{H}}=5.12, J_{\mathrm{H}-\mathrm{H}}=1.76,1 \mathrm{H}_{\mathrm{py}}\right), 7.857\left(\mathrm{~d}, 1 \mathrm{H},{ }^{3} J_{\mathrm{H}-\mathrm{H}}=\right.$ $\left.7.62,1 \mathrm{H}_{\mathrm{py}}\right), 7.547\left(\mathrm{t}, 1 \mathrm{H},{ }^{3} J_{\mathrm{H}-\mathrm{H}}=7.62, J_{\mathrm{H}-\mathrm{H}}=1.76,1 \mathrm{H}_{\mathrm{py}}\right), 7.527(\mathrm{~d}$, $\left.1 \mathrm{H},{ }^{3} J_{\mathrm{H}-\mathrm{H}}=1.75,1 \mathrm{H}_{\mathrm{Im}}\right), 7.303\left(\mathrm{~d}, 1 \mathrm{H},{ }^{3} J_{\mathrm{H}-\mathrm{H}}=1.75,1 \mathrm{H}_{\mathrm{Im}}\right), 5.757(\mathrm{~d}$, $1 \mathrm{H},{ }^{2} J_{\mathrm{H}-\mathrm{H}}=15.24, \mathrm{CH}_{2}$ bridge $), 5.561\left(\mathrm{~d}, 1 \mathrm{H},{ }^{2} J_{\mathrm{H}-\mathrm{H}}=15.24, \mathrm{CH}_{2}\right.$ bridge $)$, $3.888\left(\mathrm{~s}, 3 \mathrm{H}, \mathrm{CH}_{3}\right), 3.619$ (d, $\left.1 \mathrm{H},{ }^{3} \mathrm{~J}_{\mathrm{H}-\mathrm{H}}=3.23,1 \mathrm{H}_{\text {allyl }}\right) ; 3.224(\mathrm{vs}, 1 \mathrm{H}$, $\left.1 \mathrm{H}_{\text {allyl }}\right), 3.133$ (vs, $\left.1 \mathrm{H}, 1 \mathrm{H}_{\text {allyl }}\right), 2.312$ (vs, $\left.1 \mathrm{H}, 1 \mathrm{H}_{\text {allyl }}\right), 2.190(\mathrm{~s}, 1 \mathrm{H}$, $\left.\mathrm{CH}_{3 \text { allyl }}\right) .{ }^{13} \mathrm{C}\left\{{ }^{1} \mathrm{H}\right\}$ NMR (acetone- $\left.d_{6}, 298 \mathrm{~K}\right): \delta 176.53\left(\mathrm{C}_{\text {Im }}\right), 155.68$ $\left(\mathrm{C}_{\mathrm{py}}\right), 155.38\left(\mathrm{C}_{\mathrm{ipso}}\right), 140.52\left(\mathrm{C}_{\mathrm{py}}\right), 126.72\left(\mathrm{C}_{\mathrm{py}}\right), 125.47\left(\mathrm{C}_{\mathrm{py}}\right), 124.02$ $\left(\mathrm{C}_{\mathrm{Im}}\right), 123.84\left(\mathrm{C}_{\mathrm{Im}}\right), 121.31\left(\mathrm{C}_{\text {allyy }}\right), 70.12\left(\mathrm{C}_{\text {allyl }}\right), 54.49\left(\mathrm{CH}_{2 \text { bridge }}\right)$, $48.78\left(\mathrm{C}_{\text {allyl }}\right), 37.95\left(\mathrm{CH}_{3}\right), 23.49\left(\mathrm{CH}_{3}\right.$ allyl $\left.).\right)$. Anal. Calcd for $\mathrm{C}_{46} \mathrm{H}_{30} \mathrm{BF}_{24} \mathrm{~N}_{3} \mathrm{Ni}$ : C, 48.03; H, 2.63; N, 3.65. Found: C, 47.79; H, $2.55 ; \mathrm{N}, 3.72$.
[Ni( $\left.\left.\eta^{3}-\mathrm{CH}_{2} \mathrm{CCH}_{3} \mathrm{CH}_{2}\right)\left(\mathrm{NHC}-\kappa^{2} \mathrm{C}, \mathrm{N}\right)\right]\left[\mathrm{B}\left(\mathrm{Ar}^{\mathrm{F}}\right)_{4}\right]$ (2b). Yield: $0.45 \mathrm{~g}, 45 \%$. ${ }^{1} \mathrm{H}$ NMR (acetone- $\left.d_{6}, 298 \mathrm{~K}\right): \delta 9.01\left(\mathrm{~d}, 1 \mathrm{H},{ }^{3} J_{\mathrm{H}-\mathrm{H}}=5.28,1 \mathrm{H}_{\mathrm{py}}\right), 7.84$ $\left(\mathrm{d}, 1 \mathrm{H},{ }^{3} J_{\mathrm{H}-\mathrm{H}}=7.74,1 \mathrm{H}_{\mathrm{py}}\right), 7.57\left(\mathrm{t}, 1 \mathrm{H}, \mathrm{J}_{\mathrm{H}-\mathrm{H}}=7.62, J_{\mathrm{H}-\mathrm{H}}=1.76\right.$, $\left.1 \mathrm{H}_{\mathrm{py}}\right), 7.44\left(\mathrm{t}, 1 \mathrm{H},{ }^{3} J_{\mathrm{H}-\mathrm{H}}=6.83,1 \mathrm{H}_{\mathrm{py}}\right), 7.38\left(\mathrm{~d}, 1 \mathrm{H},{ }^{3} J_{\mathrm{H}-\mathrm{H}}=1.75\right.$, $\left.1 \mathrm{H}_{\mathrm{Im}}\right)$, overlapped with the $\mathrm{BAr}_{4}{ }^{\mathrm{F}}\left(1 \mathrm{H}_{\mathrm{Im}}\right), 5.51\left(\mathrm{~s}_{\text {broad }}, 2 \mathrm{H}, \mathrm{CH}_{2 \text { bridge }}\right)$, $4.84\left(\mathrm{~m}, 1 \mathrm{H}, 1 \mathrm{H}_{\text {Isp }}\right), 2.07\left(\mathrm{~s}, 1 \mathrm{H}, 1 \mathrm{H}_{\text {allyl }}\right), 1.68\left(\mathrm{~s}, 1 \mathrm{H}, 1 \mathrm{H}_{\text {allyl }}\right), 1.50(\mathrm{~d}$, $\left.6 \mathrm{H}, 2 \times \mathrm{CH}_{3 \text { Isp }}\right), 0.87\left(\mathrm{~s}, 1 \mathrm{H}, 1 \mathrm{H}_{\text {ally }}\right), 0.84\left(\mathrm{~s}, 1 \mathrm{H}, 1 \mathrm{H}_{\text {ally }}\right),{ }^{13} \mathrm{C}\left\{{ }^{1} \mathrm{H}\right\}$ NMR (acetone- $\left.d_{6}, 298 \mathrm{~K}\right): \delta 178.56\left(\mathrm{C}_{\mathrm{Im}}\right), 154.71\left(\mathrm{C}_{\mathrm{py}}\right), 150.02$ $\left(\mathrm{C}_{\text {ipso }}\right), 128.47\left(\mathrm{C}_{\text {allyy }}\right), 126.14\left(\mathrm{C}_{\mathrm{py}}\right), 125.66\left(\mathrm{C}_{\mathrm{py}}\right), 124.64\left(\mathrm{C}_{\mathrm{py}}\right)$, $123.08\left(\mathrm{C}_{\text {Im }}\right), 120.72\left(\mathrm{C}_{\text {Im }}\right), 53.85\left(\mathrm{CH}_{2}\right.$ bridge $), 52.61\left(\mathrm{C}_{\text {Isp }}\right), 28.98$ $\left(\mathrm{C}_{\text {allyl }}\right), 27.81\left(\mathrm{CH}_{3 \text { allyl }}\right), 22.73\left(\mathrm{CH}_{3 \text { Isp }}\right), 21.95\left(\mathrm{C}_{\text {allyl }}\right)$. Anal. Calcd for $\mathrm{C}_{48} \mathrm{H}_{34} \mathrm{BF}_{24} \mathrm{~N}_{3} \mathrm{Ni}$ : C, 48.93; H, 2.91; N, 3.57. Found: C, 49.03; H, 3.09; N, 3.64 .

[Ni $\left.\left(\eta^{3}-\mathrm{CH}_{2} \mathrm{CCH}_{3} \mathrm{CH}_{2}\right)\left(\mathrm{NHC}-\kappa^{2} \mathrm{C}, \mathrm{N}\right)\right]\left[\mathrm{B}\left(\mathrm{Ar}^{\mathrm{F}}\right)_{4}\right](2 \mathrm{c})$. Yield: $0.35 \mathrm{~g}, 35 \%$. ${ }^{1} \mathrm{H}$ NMR (acetone- $\left.d_{6}, 298 \mathrm{~K}\right): \delta 8.84\left(\mathrm{~d}, 1 \mathrm{H},{ }^{3} \mathrm{~J}_{\mathrm{H}-\mathrm{H}}=5.28,1 \mathrm{H}_{\mathrm{py}}\right), 7.81$ $\left(\mathrm{t}, 1 \mathrm{H},{ }^{3} J_{\mathrm{H}-\mathrm{H}}=7.69,1 \mathrm{H}_{\mathrm{py}}\right), 7.72\left(\mathrm{~d}, 1 \mathrm{H},{ }^{3} J_{\mathrm{H}-\mathrm{H}}=7.69,1 \mathrm{H}_{\mathrm{py}}\right), 7.72(\mathrm{~s}$, $\left.1 \mathrm{H}, 1 \mathrm{H}_{\mathrm{Im}}\right), 7.37\left(\mathrm{~s}, 1 \mathrm{H}, 1 \mathrm{H}_{\mathrm{Im}}\right), 7.29\left(\mathrm{t}, 1 \mathrm{H},{ }^{3} \mathrm{~J}_{\mathrm{H}-\mathrm{H}}=6.59,1 \mathrm{H}_{\mathrm{py}}\right), 6.66$ $\left(\mathrm{s}_{\text {broad }}, 1 \mathrm{H}, \mathrm{CH}_{2}\right.$ bridge $), 5.46\left(\mathrm{~s}_{\text {broad }}, 1 \mathrm{H}, \mathrm{CH}_{2}\right.$ bridge $), 4.03\left(\mathrm{t}, 2 \mathrm{H}, J_{\mathrm{H}-\mathrm{H}}=\right.$ $\left.7.26,2 \mathrm{H}_{\text {butyl }}\right), 3.45\left(\mathrm{~s}, 3 \mathrm{H}, 3 \mathrm{H}_{\mathrm{CH} 3 \text { allyl }}\right), 3.00\left(\mathrm{~s}, 1 \mathrm{H}, 1 \mathrm{H}_{\text {allyy }}\right), 2.24(\mathrm{~s}, 1 \mathrm{H}$, $\left.1 \mathrm{H}_{\text {allyy }}\right), 1.58\left(\mathrm{~s}, 1 \mathrm{H}, 1 \mathrm{H}_{\text {allyl }}\right), 1.21\left(\mathrm{~m}, 2 \mathrm{H}, 2 \mathrm{H}_{\text {butyl }}\right), 0.71\left(\mathrm{~s}, 1 \mathrm{H}, 1 \mathrm{H}_{\text {allyl }}\right)$ $0.75\left(\mathrm{t}, 3 \mathrm{H}, J_{\mathrm{H}-\mathrm{H}}=7.25,3 \mathrm{H}_{\text {butyl }}\right), 0.67\left(\mathrm{~m}, 2 \mathrm{H}, 2 \mathrm{H}_{\text {butyl }}\right) \cdot{ }^{13} \mathrm{C}\left\{{ }^{1} \mathrm{H}\right\}$ NMR (acetone- $\left.d_{6}, 298 \mathrm{~K}\right): \delta 175.45\left(\mathrm{C}_{\mathrm{Im}}\right), 154.52\left(\mathrm{C}_{\mathrm{py}}\right), 154.50$ $\left(\mathrm{C}_{\text {ipso }}\right), 139.47\left(\mathrm{C}_{\mathrm{py}}\right), 128.25\left(\mathrm{C}_{\text {allyl }}\right), 125.39\left(\mathrm{C}_{\mathrm{Im}}\right) ; 124.50\left(\mathrm{C}_{\mathrm{py}}\right)$, $122.12\left(\mathrm{C}_{\text {Im }}\right), 121.24\left(\mathrm{C}_{\text {Im }}\right) ; 66.61\left(\mathrm{CH}_{3}\right.$ ally $), 53.70\left(\mathrm{CH}_{2 \text { bridge }}\right), 49.87$ $\left(\mathrm{C}_{\text {buty }}\right), 47.49\left(\mathrm{C}_{\text {allyl }}\right), 27.32\left(\mathrm{C}_{\text {butyl }}\right), 21.55\left(\mathrm{C}_{\text {allyl }}\right), 21.19\left(\mathrm{C}_{\text {butyl }}\right), 12.02$ $\left(\mathrm{C}_{\text {butyl }}\right)$. Anal. Calcd for $\mathrm{C}_{49} \mathrm{H}_{36} \mathrm{BF}_{24} \mathrm{~N}_{3} \mathrm{Ni}$ : C, 49.36; H, 3.04; N, 3.52 . Found: C, 49.25; $\mathrm{H}, 3.57$; N, 3.40 .

$\left[\mathrm{Ni}\left(\eta^{3}-\mathrm{CH}_{2} \mathrm{CCH}_{3} \mathrm{CH}_{2}\right)\left(\mathrm{NHC}-\kappa^{2} \mathrm{C}, \mathrm{N}\right)\right]\left[\mathrm{B}\left(\mathrm{Ar}^{\mathrm{F}}\right)_{4}\right](2 \mathrm{~d})$. Yield: $0.62 \mathrm{~g}, 60 \%$. ${ }^{1} \mathrm{H}$ NMR (acetone- $\left.d_{6}, 298 \mathrm{~K}\right): \delta 9.006\left(\mathrm{~d}, 1 \mathrm{H},{ }^{3} \mathrm{~J}_{\mathrm{H}-\mathrm{H}}=5.56,1 \mathrm{H}_{\mathrm{py}}\right)$, $8.012\left(\mathrm{~d}, 1 \mathrm{H},{ }^{3} \mathrm{~J}_{\mathrm{H}-\mathrm{H}}=7.62,1 \mathrm{H}_{\mathrm{py}}\right), 7.993\left(\mathrm{t}, 1 \mathrm{H},{ }^{3} J_{\mathrm{H}-\mathrm{H}}=7.61,1 \mathrm{H}_{\mathrm{py}}\right)$, 
$7.501\left(\mathrm{t}, 1 \mathrm{H},{ }^{3} J_{\mathrm{H}-\mathrm{H}}=7.03,1 \mathrm{H}_{\mathrm{py}}\right)$, overlapped with the $\mathrm{BAr}_{4}{ }^{\mathrm{F}}(2 \times$ $\left.1 \mathrm{H}_{\mathrm{Im}}\right), 5.897\left(\mathrm{~d}, 1 \mathrm{H},{ }^{2} J_{\mathrm{H}-\mathrm{H}}=14.95, \mathrm{CH}_{2}\right.$ bridge $), 5.660\left(\mathrm{~d}, 1 \mathrm{H},{ }^{2} J_{\mathrm{H}-\mathrm{H}}=\right.$ $14.65, \mathrm{CH}_{2 \text { bridge }}$ ), 3.486 (vs, $1 \mathrm{H}, 1 \mathrm{H}_{\text {allyl }}$ ), 2.039 (vs, $\left.1 \mathrm{H}, 1 \mathrm{H}_{\text {allyl }}\right), 1.634$ (vs, $\left.1 \mathrm{H}, 1 \mathrm{H}_{\text {allyl }}\right), 1.943\left(\mathrm{~s}, 3 \mathrm{H}, \mathrm{CH}_{3}\right.$ allyl $)$, phenyl group signals are between 7 and 8 ppm. ${ }^{13} \mathrm{C}\left\{{ }^{1} \mathrm{H}\right\}$ NMR (acetone- $\left.d_{6}, 298 \mathrm{~K}\right): \delta 177.68$ $\left(\mathrm{C}_{\mathrm{Im}}\right), 155.93\left(\mathrm{C}_{\mathrm{py}}\right), 155.14\left(\mathrm{C}_{\mathrm{ipso}}\right), 140.56\left(\mathrm{C}_{\mathrm{py}}\right), 135.62\left(\mathrm{C}_{\mathrm{py}}\right)$, $131.18\left(\mathrm{C}_{\mathrm{py}}\right)$, overlapped with the $\mathrm{BAr}_{4}{ }^{\mathrm{F}}\left(\mathrm{C}_{4-\mathrm{Im}}\right)$ and $\left(\mathrm{C}_{5-\mathrm{Im}}\right), 121.38$ $\left(\mathrm{C}_{\text {allyl }}\right), 54.92\left(\mathrm{CH}_{2 \text { bridge }}\right), 31.17\left(\mathrm{C}_{\text {allyl }}\right), 28.59\left(\mathrm{C}_{\text {allyl }}\right), 23.28\left(\mathrm{CH}_{3 \text { allyl }}\right)$, phenyl group signals are between 120 and $130 \mathrm{ppm}$. Anal. Calcd for $\mathrm{C}_{51} \mathrm{H}_{32} \mathrm{BF}_{24} \mathrm{~N}_{3} \mathrm{Ni}$ : C, 50.53; H, 2.66; N, 3.47. Found: C, 50.70; $\mathrm{H}$, 2.78; N, 3.62.

[Ni $\left.\left(\eta^{3}-\mathrm{CH}_{2} \mathrm{CCH}_{3} \mathrm{CH}_{2}\right)\left(\mathrm{NHC}-\kappa^{2} \mathrm{C}, \mathrm{N}\right)\right]\left[B\left(\mathrm{Ar}^{\mathrm{F}}\right)_{4}\right](2 e)$. Yield: $0.51 \mathrm{~g}, 50 \%$. ${ }^{1} \mathrm{H}$ NMR (acetone- $\left.d_{6}, 298 \mathrm{~K}\right): \delta 8.87\left(\mathrm{~d}, 1 \mathrm{H},{ }^{3} J_{\mathrm{H}-\mathrm{H}}=5.11, \mathrm{H}_{\mathrm{py}}\right), 7.72$ $\left(\mathrm{t}, 1 \mathrm{H},{ }^{3} J_{\mathrm{H}-\mathrm{H}}=7.95, \mathrm{H}_{\mathrm{py}}\right), 7.45\left(\mathrm{~d}, 1 \mathrm{H},{ }^{3} J_{\mathrm{H}-\mathrm{H}}=7.72, \mathrm{H}_{\mathrm{py}}\right), 7.34(\mathrm{~m}$, $\left.1 \mathrm{H}, \mathrm{H}_{\mathrm{py}}\right), 7.86\left(\mathrm{~m}, 2 \mathrm{H}, \mathrm{H}_{\text {benzo }}\right), 7.21\left(\mathrm{~d}-\mathrm{t}, 2 \mathrm{H},{ }^{3} J_{\mathrm{H}-\mathrm{H}}=7.51, \mathrm{H}_{\text {benzo }}\right)$, 5.89 ( $\mathrm{s}_{\text {broad }}, 2 \mathrm{H}, \mathrm{CH}_{2}$ bridge $), 3.38\left(\mathrm{~s}, 3 \mathrm{H}, \mathrm{CH}_{3}\right), 3.92\left(\mathrm{~s}, 3 \mathrm{H}, \mathrm{CH}_{3}\right.$ allyl $)$, $2.10\left(\mathrm{~s}, 1 \mathrm{H}, 1 \mathrm{H}_{\text {allyl }}\right), 2.05\left(\mathrm{~s}, 1 \mathrm{H}, 1 \mathrm{H}_{\text {allyl }}\right), 0.65\left(\mathrm{~s}, 1 \mathrm{H}, 1 \mathrm{H}_{\text {allyl }}\right), 0.64(\mathrm{~s}$, $\left.1 \mathrm{H}, 1 \mathrm{H}_{\text {ally }}\right) .{ }^{13} \mathrm{C}\left\{{ }^{1} \mathrm{H}\right\}$ NMR (acetone- $\left.d_{6}, 298 \mathrm{~K}\right): \delta 155.56\left(\mathrm{C}_{\mathrm{py}}\right)$, $155.11\left(\mathrm{C}_{\text {ipso }}\right), 153.58\left(\mathrm{C}_{\text {Im }}\right), 140.50\left(\mathrm{C}_{\text {benzo }}\right), 129.12\left(\mathrm{C}_{\mathrm{Im}}\right), 128.08$ $\left(\mathrm{C}_{\mathrm{Im}}\right), 126.56\left(\mathrm{C}_{\text {allyl }}\right), 126.28\left(\mathrm{C}_{\text {benzo }}\right), 125.55\left(\mathrm{C}_{\mathrm{py}}\right), 124.46\left(\mathrm{C}_{\text {benzo }}\right)$, $111.82\left(\mathrm{C}_{\mathrm{py}}\right), 111.18\left(\mathrm{C}_{\mathrm{py}}\right), 67.52\left(\mathrm{CH}_{3}\right), 50.83\left(\mathrm{CH}_{2}\right.$ bridge $), 34.65$ $\left(\mathrm{CH}_{3}\right.$ allyl $) ; 28.52\left(\mathrm{C}_{\text {allyl }}\right), 23.46\left(\mathrm{C}_{\text {allyl }}\right)$. Anal. Calcd for $\mathrm{C}_{50} \mathrm{H}_{32} \mathrm{BF}_{24} \mathrm{~N}_{3} \mathrm{Ni}$ : C, 50.03; H, 2.69; N, 3.50. Found: C, 49.91; H, $2.51 ; \mathrm{N}, 3.33$.

$\left[\mathrm{Ni}\left(\eta^{3}-\mathrm{CH}_{2} \mathrm{CCH}_{3} \mathrm{CH}_{2}\right)\left(\mathrm{NHC}-\kappa^{2} \mathrm{C}, \mathrm{N}\right)\right]\left[\mathrm{B}\left(\mathrm{Ar}^{\mathrm{F}}\right)_{4}\right](2 \mathrm{f})$. Yield: $0.57 \mathrm{~g}, 55 \%$. ${ }^{1} \mathrm{H}$ NMR (acetone- $\left.d_{6}, 298 \mathrm{~K}\right): \delta 9.05\left(\mathrm{~d}, 1 \mathrm{H},{ }^{3} \mathrm{~J}_{\mathrm{H}-\mathrm{H}}=4.69,1 \mathrm{H}_{\mathrm{py}}\right), 8.09$ $\left(\mathrm{t}, 1 \mathrm{H}, J_{\mathrm{H}-\mathrm{H}}=7.92, J_{\mathrm{H}-\mathrm{H}}=1.76,1 \mathrm{H}_{\mathrm{py}}\right), 8.00\left(\mathrm{~d}, 1 \mathrm{H},{ }^{3} J_{\mathrm{H}-\mathrm{H}}=7.92\right.$, $\left.1 \mathrm{H}_{\mathrm{py}}\right), 7.58\left(\mathrm{t}, 1 \mathrm{H}, J_{\mathrm{H}-\mathrm{H}}=5.57, J_{\mathrm{H}-\mathrm{H}}=1.47 \mathrm{~Hz} 1 \mathrm{H}_{\mathrm{py}}\right), 5.83\left(\mathrm{~s}_{\text {broad }}, 1 \mathrm{H}\right.$, $\mathrm{CH}_{2 \text { bridge }}$ ), 5.00 ( $\mathrm{s}_{\text {broad }} 1 \mathrm{H}, \mathrm{CH}_{2}$ bridge $), 3.88\left(\mathrm{~s}, 3 \mathrm{H}, \mathrm{CH}_{3}\right), 3.87$ (vs, $1 \mathrm{H}$, $\left.1 \mathrm{H}_{\text {allyl }}\right), 3.66$ (vs, $\left.1 \mathrm{H}, 1 \mathrm{H}_{\text {allyy }}\right), 2.31$ (vs, $\left.1 \mathrm{H}, 1 \mathrm{H}_{\text {allyy }}\right), 2.21$ (s, $3 \mathrm{H}$, $\left.\mathrm{CH}_{3 \text { allyl }}\right), 0.83$ (vs, $\left.1 \mathrm{H}, 1 \mathrm{H}_{\text {allyl }}\right),{ }^{13} \mathrm{C}\left\{{ }^{1} \mathrm{H}\right\}$ NMR (acetone- $d_{6}, 298 \mathrm{~K}$ ): $\delta$ $158.79\left(\mathrm{C}_{\mathrm{Im}}\right), 155.36\left(\mathrm{C}_{\mathrm{py}}\right), 154.70\left(\mathrm{C}_{\text {ipso }}\right), 140.70\left(\mathrm{C}_{\mathrm{py}}\right), 129.81$ $\left(\mathrm{BAr}_{4}{ }^{\mathrm{F}}\right), 128.14\left(\mathrm{C}_{\text {allyy }}\right), 126.81\left(\mathrm{C}_{\mathrm{py}}\right), 125.53\left(\mathrm{C}_{\mathrm{py}}\right), 124.86\left(\mathrm{C}_{\mathrm{Im}}\right)$, $123.59\left(\mathrm{C}_{\mathrm{Im}}\right), 51.46\left(\mathrm{CH}_{2}\right.$ bridge $), 36.16\left(\mathrm{CH}_{3}\right), 36.00\left(\mathrm{C}_{\text {ally }}\right), 28.27$ $\left(\mathrm{C}_{\text {allyl }}\right), 23.24\left(\mathrm{CH}_{3}\right.$ allyl $)$. Anal. Calcd for $\mathrm{C}_{46} \mathrm{H}_{28} \mathrm{BCl}_{2} \mathrm{~F}_{24} \mathrm{~N}_{3} \mathrm{Ni}$ : C, 45.32; H, 2.31; N, 3.45. Found: C, 45.37; H, 2.46; N, 3.63.

Crystal Structure Analysis. A sample of 1d was recrystallized from a mixture of diethyl ether and petroleum ether (bp $40-60{ }^{\circ} \mathrm{C}$ ) at $-20^{\circ} \mathrm{C}$. A crystal of $\mathbf{1 d}$ suitable for X-ray structural determination was mounted on a glass fiber and then transferred to the cold nitrogen gas stream of a Bruker Smart APEX CCD three-circle diffractometer $(T=$ $100 \mathrm{~K})$ with a sealed-tube source and graphite-monochromated Mo $\mathrm{K} \alpha$ radiation $(\lambda=0.71073 \AA)$ at the Servicio Central de Ciencia y Tecnología de la Universidad de Cádiz. Four sets of frames were recorded over a hemisphere of the reciprocal space by $\omega$ scans with $\delta(\omega)=0.30$ and an exposure of $10 \mathrm{~s}$ per frame. Correction for absorption was applied by scans of equivalents using the SADABS program. ${ }^{39}$ An insignificant crystal decay correction was also applied. The structure was solved by direct methods and refined on $F^{2}$ by fullmatrix least squares (SHELX97) ${ }^{40}$ by using all unique data. All nonhydrogen atoms were refined anisotropically with hydrogen atoms included in calculated positions (riding model). The allyl ligand was refined split in two complementary orientations with site occupation factors of 0.71 and 0.29 , respectively. Also, three disordered $\mathrm{CF}_{3}$ groups in the anion were refined split into two complementary orientations using displacement parameter restraints. The program ORTEP- 3 was used for plotting. ${ }^{41}$ Table 5 summarizes the crystal data and data collection and refinement details for 1d. CCDC 836795 contains supplementary crystallographic data for this paper. These data can be obtained free of charge from The Cambridge Crystallographic Data Centre via www.ccdc.cam.ac.uk/data_request/cif.

Catalytic Oligomerization Studies. A Schlenk tube was loaded with styrene, 4-methylstyrene, or $\alpha$-methylstyrene (10 mmol), 1,2dichloroethane $(1 \mathrm{~mL})$, and the corresponding catalyst $(1 \mathrm{~mol} \%)$ under argon. The system was heated to $60{ }^{\circ} \mathrm{C}$ using a paraffin bath. The reaction time was measured from the moment the compounds were introduced at $60{ }^{\circ} \mathrm{C}$. The reaction was quenched by addition of methanol. The volatiles were pumped off, and the residue was treated with methanol to yield a white oil of but-1-ene-1,3-diyldibenzene, which was dried under vacuum. The distyrene was dissolved in
Table 5. Summary of Crystallographic Data for 1d

\begin{tabular}{|c|c|}
\hline formula & $\mathrm{C}_{54} \mathrm{H}_{40} \mathrm{BF}_{24} \mathrm{~N}_{3} \mathrm{NiO}$ \\
\hline $\mathrm{fw}$ & 1272.41 \\
\hline$T(\mathrm{~K})$ & 100 \\
\hline cryst size $(\mathrm{mm})$ & $0.59 \times 0.54 \times 0.27$ \\
\hline cryst system & monoclinic \\
\hline space group & $\mathrm{C} 2 / \mathrm{c}$ \\
\hline \multicolumn{2}{|l|}{ cell params $(\AA ̊, \mathrm{deg})$} \\
\hline$a, \AA$ & $30.180(6)$ \\
\hline$b, \AA$ & $12.912(3)$ \\
\hline$c, \AA$ & $28.568(6)$ \\
\hline$\beta, \operatorname{deg}$ & $93.67(3)$ \\
\hline$V\left(\AA^{3}\right)$ & $11109(4)$ \\
\hline$Z$ & 8 \\
\hline$\rho_{\text {calcd }}\left(\mathrm{g} \mathrm{cm}^{-3}\right)$ & 1.522 \\
\hline$\mu(\mathrm{Mo} \mathrm{K} \alpha)\left(\mathrm{mm}^{-1}\right)$ & 0.472 \\
\hline$F(000)$ & 5136 \\
\hline $\max -\min$ transmissn factors & $1.000-0.737$ \\
\hline range for data collection ( $\mathrm{deg}$ ) & $1.43<\theta<25.14$ \\
\hline index ranges & $\begin{array}{l}-35<h>34 ;-15<k>14 \\
-32<l>33\end{array}$ \\
\hline no. of rflns collected & 36542 \\
\hline no. of unique rflns & 9795 \\
\hline no. of obsd rflns $\left(I>2 \sigma_{I}\right)$ & 8795 \\
\hline no. of params & 774 \\
\hline final R1, wR2 values $\left(I>2 \sigma_{I}\right)$ & $0.0982,0.2305$ \\
\hline final R1, wR2 values (all data) & $0.1076,0.2373$ \\
\hline residual electron density peaks (e $\AA^{-3}$ ) & $1.681,-0.767$ \\
\hline
\end{tabular}

petroleum ether $(10 \mathrm{~mL})$ and filtered through a silica gel plug. The silica gel was washed with several small portions of petroleum ether in order to remove all traces of but-1-ene-1,3-diyldibenzene. The resulting residue was dried under vacuum to constant weight.

Catalytic Hydrosilylation Studies. A Schlenk tube was loaded with olefin $(10 \mathrm{mmol}), \mathrm{PhSiH}_{3}(20 \mathrm{mmol}), 1,2$ - dichloroethane $(1 \mathrm{~mL})$, and the corresponding catalyst $(1 \mathrm{~mol} \%)$ under argon. The system was heated to $60{ }^{\circ} \mathrm{C}$ using a paraffin bath over $4 \mathrm{~h}$. The reaction time was measured from the moment it was introduced at $60{ }^{\circ} \mathrm{C}$. After this period of time, a dark brown solution was obtained. The volatiles were pumped off, and the residue was treated with petroleum ether, which was filtered through a silica gel plug. The silica gel was washed with several small portions. The resulting residue was dried under vacuum, and the corresponding hydrosilylation products were observed in the form of yellowish oils. Their NMR properties were compared with data in the literature. ${ }^{35 a, 36}$

4-Fluorostyrene Hydrosilylation Kinetic Studies. In a NMR tube was prepared a mixture of 4-fluorostyrene $(0.5 \mathrm{mmol}), \mathrm{PhSiH}_{3}$ $(1 \mathrm{mmol}), 1,2$-dichloroethane $(300 \mu \mathrm{L})$, benzene- $d_{6}(100 \mu \mathrm{L})$, and the corresponding catalyst $(1 \mathrm{~mol} \%)$ under argon in a bath containing $\mathrm{N}_{2}(\mathrm{l}) / \mathrm{EtOH}$. This mixture was monitored by NMR at $60{ }^{\circ} \mathrm{C}:{ }^{19} \mathrm{~F}$ NMR spectra were measured every $180 \mathrm{~s}$ during $1 \mathrm{~h}$. Their NMR properties were compared with data in the literature and confirmed by CG-MS.

${ }^{1} \mathrm{H}$ NMR for $\{1$-(4-fluorophenyl)ethyl $\}$ phenylsilane (benzene- $d_{6}$, $298 \mathrm{~K}): \delta 1.19\left(\mathrm{~d}, 3 \mathrm{H}, J_{\mathrm{H}-\mathrm{H}}=6.8, \mathrm{CH}_{3}\right), 2.73\left(\mathrm{~m}, 2 \mathrm{H}, \mathrm{CH}_{2}\right), 4.15(\mathrm{vd}$, $\mathrm{SiH}_{2}$ ), aromatic signals $7.6-7.0 \mathrm{ppm}$.

${ }^{1} \mathrm{H}$ NMR (4-fluorophenylethyl)phenylsilane (benzene- $\left.d_{6}, 298 \mathrm{~K}\right): \delta$ $1.25\left(\mathrm{~m}, 2 \mathrm{H}, \mathrm{CH}_{2}\right), \delta: 2.63\left(\mathrm{~m}, 2 \mathrm{H}, \mathrm{CH}_{2}\right), 4.21\left(\mathrm{vd}, \mathrm{SiH}_{2}\right)$, aromatic signals $7.6-7.0 \mathrm{ppm}$.

\section{ASSOCIATED CONTENT}

\section{Supporting Information}

Figures, tables, and a CIF file giving catalytic screening results and crystallographic data for compound 1d. This material is available free of charge via the Internet at http://pubs.acs.org. 


\section{AUTHOR INFORMATION}

\section{Corresponding Author}

*E-mail: carmen.puerta@uca.es (M.C.P.); pedro.valerga@uca. es (P.V.).

\section{Notes}

The authors declare no competing financial interest.

\section{ACKNOWLEDGMENTS}

We thank the Spanish MICINN (Projects CTQ2007-60137/ BQU and CTQ2010-15390) and "Junta de Andalucia" (PAIDIFQM188 and Project of Excellence P08-FQM-03538) for financial support. L.B.J. acknowledges fellowship support from "Junta de Andalucia" (ref. 2009-126).

\section{REFERENCES}

(1) Wanzlick. Angew. Chem., Int. Ed. 1962, 1, 75-80.

(2) Wanzlick. Angew. Chem., Int. Ed. 1968, 7, 141-142.

(3) Arduengo, A. J.; Harlow, R. L.; Kline, M. J. Am. Chem. Soc. 1991 113, 361.

(4) Hermann, W. A. Angew. Chem., Int. Ed. 2002, 41, 1290.

(5) (a) Penka, E. F.; Schaläpfer, C. W.; Atanasov, M.; Albrecht, M.; Daul, C. J. Organomet. Chem. 2007, 692, 5709. (b) Díez-González, S.; Nolan, S. P. Coord. Chem. Rev. 2007, 251, 874.

(6) Zang, Y.; Ngeow, K. C.; Ying, J. Y. Org. Lett. 2007, 9, 3495.

(7) (a) McCormick, M. M.; Duong, H. A.; Zuo, G.; Louie, J. J. Am. Chem. Soc. 2005, 127, 5030. (b) Duong, H. A.; Cross, M. J.; Louie, J. J. Am. Chem. Soc. 2004, 126, 11438. (c) Louie, J.; Gibby, J. E.; Farnworth, M. V.; Tekavec, T. N. J. Am. Chem. Soc. 2002, 124, 15188. (d) Tekavec, T. N.; Zuo, G.; Simon, K.; Louie, J. J. Org. Chem. 2006, 71,5834 .

(8) For an example of cycloaddition of unsaturated hydrocarbons, aldehydes, and ketones, see: Tekavec, T. N.; Louie, J. J. Org. Chem. 2008, 73, 2641.

(9) For a recent review about $[2+2+2]$ cycloaddition reactions, see: Chopade, P. R.; Louie, J. Adv. Synth. Catal. 2006, 348, 2307.

(10) (a) Omar-Amrani, R.; Thomas, A.; Brenner, E.; Schneider, R.; Fort, Y. Org. Lett. 2003, 5, 2311. (b) Kuhl, S.; Fort, Y.; Schneider, R. J. Organomet. Chem. 2005, 690, 6169. (c) Desmarets, C.; Schneider, R.; Fort, Y. J. Org. Chem. 2002, 67, 3029. (d) Gradel, B.; Brenner, E.; Schneider, R.; Fort, Y. Tetrahedron Lett. 2001, 42, 5689.

(11) (a) Xi, Z.; Zhang, X.; Chen, W.; Fu, S.; Wang, D. Organometallics 2007, 26, 6636. (b) Inamoto, K.; Kuroda, J.-i.; Sakamoto, T.; Hiroya, K. Synthesis 2007, 2853. (c) Inamoto, K.; Kuroda, J.-i.; Sakamoto, T.; Hiroya, K. Synthesis 2007, 2853.

(12) Buchowicz, W; Koziol, A.; Jerzykiewicz, L. B.; Lis, T.; Pasynkiewicz, S.; Pecherzewska, A.; Pietrzykowski, A. J. Mol. Catal. A 2006, 257, 118-123.

(13) Moreno-Mañas, M.; Pérez, M.; Pleixats, R. J. Org. Chem. 1996, $61,2346$.

(14) (a) Matsubara, K; Ueno, K.; Koga, Y.; Hara, K. J. Org. Chem. 2007, 72, 5069. (b) Kelly, R. A. III; Scott, N. M.; Díez-González, S.; Stevens, E. D.; Nolan, S. P. Organometallics 2005, 24, 3442.

(15) Ritleng, V.; Oerel, A. M.; Chetcuti, M. J. Dalton Trans. 2010, 39, 8153-8160.

(16) (a) Inamoto, K.; Kuroda, J.-i.; Kwon, E.; Hiroya, K.; Doi, T. J. Organomet. Chem. 2009, 694, 389. (b) Kuroda, J.-i.; Inamoto, K.; Hiroya, K.; Doi, T. Eur. J. Org. Chem. 2009, 2251. (c) Zhou, Y.; Xi, Z.; Chen, W.; Wang, D. Organometallics 2008, 27, 5911. (d) Liao, C.-Y.; Chan, K.-T.; Chang, Y.-C.; Chen, C.-Y.; Tu, C.-Y.; Hu, C.-H.; Lee, H. M. Organometallics 2007, 26, 5826. (e) Lee, C.-C.; Ke, W.-C; Chan, K.-T.; Lai, C.-L.; Hu, C.-H.; Lee, H. M. Chem. Eur. J 2007, 13, 582. (f) Inamoto, K.; Kuroda, J.-i.; Hiroya, K.; Noda, Y.; Watanabe, M.; Sakamoto, T. Organometallics 2006, 25, 3095. (g) Chiu, P. L.; Lai, C.-L.; Chang, C.-F.; Hu, C.-H.; Lee, H. M. Organometallics 2005, 24, 6169. (h) McGuinness, D. S.; Cavell, K. J.; Skelton, B. W.; White, A. H. Organometallics 1999, 18, 1596.
(17) (a) Liu, A.; Zhang, X.; Chen, W. Organometallics 2009, 28, 4868. (b) Berding, J.; Lutz, M.; Spek, A. L.; Bouwman, E. Organometallics 2009, 28, 1845. (c) Gu, S.; Chen, W. Organometallics 2009, 28, 909. (d) Xi, Z.; Liu, B.; Chen, W. J. Org. Chem. 2008, 73, 3954. (e) Matsubara, K.; Ueno, K.; Shibata, Y. Organometallics 2006, 25, 3422.

(18) Dible, B. R.; Sigman, M. S. Inorg. Chem. 2006, 45, 20.

(19) Silva, L. C.; Gomes, P. T.; Veiros, L. F.; Pascu, S. I.; Duarte, M. T.; Namorado, S.; Ascenso, J. R.; Dias, A. R. Organometallics 2006, $25,4391-4403$.

(20) Cámpora, J.; de la Tabla, L. O.; Palma, P.; Alvarez, E.; Lahoz, F.; Mereiter, K. Organometallics 2006, 25, 3314-3316.

(21) (a) S, S.; Noh, E. K.; Lee, B. Y.; Han, J. W. J. Organomet. Chem. 2008, 693, 2171. (b) Benson, S.; Payne, B.; Waymouth, R. M. J. Polym. Sci., Part A 2007, 45, 3637.

(22) (a) McGuinness, D. S.; Mueller, W.; Wasserscheid, P.; Cavell, K. J; Skelton, B. W.; White, A. H.; Englert, U. Organometallics 2002 21, 175. (b) Mackinnon, A. L.; Baird, M. C. J. Organomet. Chem. 2003, $683,114$.

(23) McGuinness, D. S.; Saendig, N.; Yates, B. F.; Cavell, K. J. J. Am. Chem. Soc. 2001, 123, 4029.

(24) McGuinness, D. S.; Cavell, K. J. Organometallics 2000, 19, 4918.

(25) Díez-González, S.; Marion, N.; Nolan, S. P. Chem. Rev. 2009, 109, 3612-3676.

(26) Oertel, A. M.; Ritleng, V.; Chetcuti, M. J.; Veiros, L. F. J. Am. Chem. Soc. 2010, 132, 13588-13589.

(27) Oertel, A. M.; Freudenreich, J.; Gein, J.; Ritleng, V.; Veiros, L. F.; Chetcuti, M. J. Organometallics 2011, 30, 3400-3411.

(28) (a) Poyatos, M.; Mata, J. A.; Peris, E. Chem. Rev. 2009, 109, 3677-3707. (b) Oliver, S.; Yang, L.; Raubenheimer, H. G.; Albrecht, M. Chem. Rev. 2009, 109, 3445-3478.

(29) Jiménez-Tenorio, M.; Puerta, M. C.; Salcedo, I.; Valerga, P.; de los Rios, I.; Mereiter, K. Dalton Trans 2009, 1842-1852.

(30) (a) Gründemann, A.; Kovacevic; Albrecht, M.; Faller, J. W.; Crabtree, R. H. J. Am. Chem. Soc. 2002, 124, 10473. (b) Jahnke, C. M.; Pape, T.; Hahn, F. E. Eur. J. Inorg. Chem. 2009, 13, 1960-1969.

(31) (a) Campora, J.; Carmona, E.; Conejo, M. M. ES Patent 2200698, 2004. (b) Campora, J.; Conejo, M. M.; Reyes, M. L.; Mereiter, K.; Passaglia, E. Chem. Commun. 2003, 78-79.

(32) (a) Ascenso, J. R.; Dias, A. R; Gomes, P. T.; Ramao, C. C.; Pham, Q.-T.; Neibecker, D; Tkatchenko, I. Macromolecules 1989, 22, 998-1000. (b) Hong, M. S.; Qing, S.; Dong, M. H.; Wan, F. L.; Qi, S.; Yong, Z. Organometallics 2004, 24, 331-334.

(33) Ritleng, V.; Barth, C.; Brenner, E.; Milosevic, S.; Chetcuti, M. J. Organometallics 2008, 27, 4223-4228.

(34) Fernández, F. E.; Puerta, M. C.; Valerga, P. Organometallics 2011, 30, 5793-5802.

(35) (a) Fontaine, F. G.; Neguyen, R. V.; Zargarian, D. Can. J. Chem. 2003, 81, 129. (b) Chen, Y.; Sui-Seng, C.; Boucher, S.; Zargarian, D. Organometallics 2005, 24, 149.

(36) (a) Fu, P. F.; Brard, Y. L.; Marks, T. J. J. Am. Chem. Soc. 1995, 117,7157

(37) Billington, D. C. In Comprehensive Organic Synthesis; Trost, B. M., Fleming, I., Eds.; Pergamon Press: Oxford, U.K., 1991; Vol. 3, p 423.

(38) Kesti, M. R.; Coates, G. W.; Waymouth, R. M. J. Am. Chem. Soc. 1992, 114, 9679.

(39) Sheldrick, G. M. SADABS 2001 version; University of Göttingen, Göttingen, Germany, 2001.

(40) (a) Sheldrick, G. M. SHELXTL version 6.10, Crystal Structure Analysis Package; Bruker AXS, Madison, WI, 2000. (b) Sheldrick, G. M. Acta Crystallogr. 2008, A64, 112-122.

(41) Farrugia, L. J. ORTEP-3 for Windows, version 1.076. J. Appl. Crystallogr. 1997, 30, 565. 